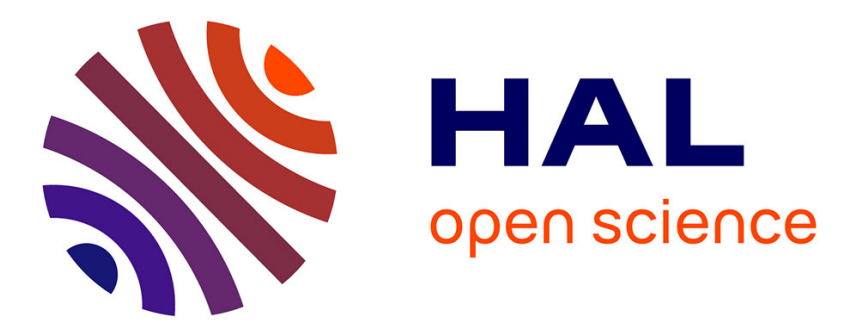

\title{
Synthesis, Structure, and Bonding of Bimetallic Bridging Borylene and Boryl Complexes
}

Koushik Saha, Sourav Kar, Urminder Kaur, Thierry Roisnel, Sundargopal Ghosh

\section{- To cite this version:}

Koushik Saha, Sourav Kar, Urminder Kaur, Thierry Roisnel, Sundargopal Ghosh. Synthesis, Structure, and Bonding of Bimetallic Bridging Borylene and Boryl Complexes. Organometallics, 2020, 39 (23), pp.4362-4371. 10.1021/acs.organomet.0c00532 . hal-03122462

\section{HAL Id: hal-03122462 \\ https://hal.science/hal-03122462}

Submitted on 16 Feb 2021

HAL is a multi-disciplinary open access archive for the deposit and dissemination of scientific research documents, whether they are published or not. The documents may come from teaching and research institutions in France or abroad, or from public or private research centers.
L'archive ouverte pluridisciplinaire HAL, est destinée au dépôt et à la diffusion de documents scientifiques de niveau recherche, publiés ou non, émanant des établissements d'enseignement et de recherche français ou étrangers, des laboratoires publics ou privés. 


\title{
Synthesis, structure and bonding of bimetallic bridging borylene and boryl complexes
}

\author{
Koushik Saha, [a] Sourav Kar, [a],§ Urminder Kaur,[a],\$ Thierry Roisnel[b] and Sundargopal Ghosh*[a]
}

[a] Dr. K. Saha, Mr. S. Kar, Ms. U. Kaur, Prof. Dr. S. Ghosh

Department of Chemistry, Indian Institute of Technology Madras, Chennai 600036, India.

Tel: +91 44-22574230; Fax: +91 44-22574202

E-mail: sghosh@iitm.ac.in

[b] Dr. Thierry Roisnel

Univ Rennes, CNRS, ISCR (Institut des Sciences Chimiques de Rennes), UMR 6226, F-35000 Rennes, France

\begin{abstract}
New synthetic route for the synthesis of diruthenium boryl complexes has been established. Thermolysis of an arachno-ruthenaborane, $\left[\left(\mathrm{Cp}^{*} \mathrm{Ru}\right)_{2} \mathrm{~B}_{3} \mathrm{H}_{8}\left(\mathrm{CS}_{2} \mathrm{H}\right)\right](\mathbf{1})\left(\mathrm{Cp}^{*}=\eta^{5}-\mathrm{C}_{5} \mathrm{Me}_{5}\right)$ with phenyl acetylene, led to the formation of bridging boryl borylene complex as $\left[(\mathrm{Cp} * \mathrm{Ru})_{2}\left(\mu-\mathrm{HBS}_{2} \mathrm{CH}_{2}-\kappa^{2} B: \kappa^{2} S\right)\left\{\mu-\mathrm{B}\left(\mathrm{C}_{6} \mathrm{H}_{4}\right) \mathrm{C}\left(\mathrm{CH}_{3}\right)-\kappa^{2} B: \kappa^{2} C\right\}\right](2)$. In parallel to the formation of 2, the reaction also yielded [(Cp* Ru) $(\mu-\mathrm{H}) \mathrm{BH}\{\mathrm{HC}=\mathrm{C}(\mathrm{H}) \mathrm{Ph}\}\{\mathrm{SC}(\mathrm{H}) \mathrm{S}\}](\mathbf{3 a})$ and $\left[\left(\mathrm{Cp}^{*} \mathrm{Ru}\right)(\mu-\mathrm{H}) \mathrm{BH}\left(\mathrm{PhC}=\mathrm{CH}{ }_{2}\right)\{\mathrm{SC}(\mathrm{H}) \mathrm{S}\}\right](\mathbf{3 b})$. To understand the reaction pathways for the formation of 2 , we have thermolyzed 1 in toluene that afforded ruthenium bridging bis(boryl) complex, [(Cp*Ru) $\left.)_{2}\left(\mu-\mathrm{HBS}_{2} \mathrm{CH}_{2}-\kappa^{2} B: \kappa^{2} S\right)\left\{\mu, \eta^{2}: \eta^{2}-\mathrm{SBH}\right\}\right]$ (4) along with nido-ruthenathiaborane [(Cp*Ru) $2(\mathrm{Me})-$ $\left.\left(\mathrm{S}_{2} \mathrm{~B}_{2} \mathrm{H}_{3}\right)\right]$ (5). Nido-5 is structurally and el ectronically similar with nido-[(Cp+Ru $\left.)_{2}\left(\mathrm{~S}_{2} \mathrm{C}_{2} \mathrm{Ph}_{2}\right)\right]\left(\mathrm{Cp}^{+}=\eta^{5}-\mathrm{C}_{5} \mathrm{Me}_{4} \mathrm{Et}\right)$, which can be generated from the room temperature reaction of $\left[(\mathrm{Cp}+\mathrm{Ru})_{2}\left(\mu, \eta^{1}: \eta^{1}-\mathrm{S}_{2}\right)\left(\mu, \eta^{2}: \eta^{2}-\mathrm{S}_{2}\right)\right]$ with diphenylacetylene. Thus, nido-5 can be defined as a true mimic of organometallic cluster nido-[(Cp+Ru $\left.)_{2}\left(\mathrm{~S}_{2} \mathrm{C}_{2} \mathrm{Ph}_{2}\right)\right]$. Complex $\left[(\mathrm{Cp} * \mathrm{Ru})_{2}\left(\mu, \eta^{1}: \eta^{1}-\mathrm{S}_{2}\right)\left(\mu, \eta^{2}: \eta^{2}-\mathrm{S}_{2}\right)\right](6)$ the Cp* analogue of $\left[\left(\mathrm{Cp}^{+} \mathrm{Ru}\right)_{2}\left(\mu, \eta^{1}: \eta^{1}-\mathrm{S}_{2}\right)\left(\mu, \eta^{2}: \eta^{2}-\mathrm{S}_{2}\right)\right]$, can be isolated from the reaction of $\mathrm{Li}\left[\mathrm{BH}_{2} \mathrm{~S}_{3}\right] \mathrm{with}^{2}\left[\mathrm{Cp}^{*} \mathrm{RuCl}_{2}\right] 2$ along with a diruthenium boryl complex, $\left[(\mathrm{Cp} * \mathrm{Ru})_{2}\left(\mu, \eta^{1}: \eta^{1}-\mathrm{S}_{2}\right)\left(\mu-\mathrm{S}_{2} \mathrm{BH}-\kappa^{1} B: \kappa^{2} S: \kappa^{2} S^{2}\right)\right]$ (7) in which the boryl unit $\left(\mathrm{S}_{2} \mathrm{BH}\right)$ possesses no bulky heterocyclic ligand. Theoretical studies were performed to shed light on the bonding of these borylene and boryl complexes. The theoretical calculations reveal that the stability of these complexes is due to the strong interaction between the borylene and boryl unit with the ruthenium centers.
\end{abstract}

\section{INTRODUCTION}

Boron has enriched the coordination chemistry of both main group and the transition metals as it can form both electron precise (2c-2e) as well as electron deficient (3c-2e) bond/s with itself and other el ements. ${ }^{1}$ As a result, different types of boron-containing compounds having unusual geometry and diverse reactivity, were reported over the years. $^{2-3}$ Other than practical applications in organic chemistry, boron containing compounds have received significant attention in experimental as well as theoretical chemistry. Discovery of hydroboration reaction by $\mathrm{H}$. C. Brown has surged the development of organoborane reagents. 4,5 Hydroboration of carbon-carbon multiple bonds using different metal catalysts allowed this field to grow further. ${ }^{6}$ Note that, the introduction of boryl moiety into $\mathrm{C}=\mathrm{C}$ or $\mathrm{C} \equiv \mathrm{C}$ bond using hydroboration reaction is one of the most effective ways to synthesize organoboronates with high regio, chemo, and stereoselectivity. ${ }^{7}$ As a result, valuable metal-based catalysts are developed that offer notable advancement in this field. The group 9 metal-based systems, in particular Rh and Ir complexes, are the most commonly employed catalysts used for such organic transformations. ${ }^{8}$

Although the reaction of alkyne/s with metallaborane/s was recognized in 1978, not many examples are known till date.9,10 Grimes et al. demonstrated the hydroboration reaction of $\left[(\mathrm{CpCo}) \mathrm{B}_{4} \mathrm{H}_{8}\right]$ with acetylene that led to the formation of metallacarborane cluster, $\left[(\mathrm{CpCo}) \mathrm{C}_{2} \mathrm{~B}_{3} \mathrm{H}_{7}\right] .9 \mathrm{a}$ Subsequently, Fehlner et al. examined the reactivity of a series of open clusters with alkynes, for example, nido$\left[\left(\mathrm{Cp}^{*} \mathrm{Ru}\right)_{2}(\mu-\mathrm{H})_{2} \mathrm{~B}_{3} \mathrm{H}_{7}\right]$, nido- $\left[(\mathrm{Cp} * \mathrm{Rh})_{2} \mathrm{~B}_{3} \mathrm{H}_{7}\right]$ and arachno-
$\left[\left(\mathrm{PMe}_{3}\right)_{2} \mathrm{IrH}(\mathrm{CO}) \mathrm{B}_{8} \mathrm{H}_{12}\right] .{ }^{10}$ Interestingly, when the terminal or internal alkynes were treated with nido- $\left[\left(\mathrm{Cp}^{*} \mathrm{Ru}\right)_{2}(\mu-\right.$ $\mathrm{H})_{2} \mathrm{~B}_{3} \mathrm{H}_{7}$, this led to the formation of metallacarborane clusters.10a In contrast, the Rh-analogue nido$\left[(\mathrm{Cp} * \mathrm{Rh})_{2} \mathrm{~B}_{3} \mathrm{H}_{7}\right]$ acts as al kyne cyclotrimerization catalyst. ${ }^{10 \mathrm{a}}$ Subsequently, we have demonstrated the utility of arachno$\left[(\mathrm{Cp} * \mathrm{RuCO})_{2} \mathrm{~B}_{2} \mathrm{H}_{6}\right]$ as a catalyst for the cyclotrimerization of various terminal and internal alkynes. ${ }^{9 c}$ The usefulness of various borate and borane species of transition metals have also been established that yielded metal-vinylborane and alkeneborane complexes. ${ }^{11}$ As a result, we were interested to explore the reactivity of arachno-ruthenaborane $\left[(\mathrm{Cp} * \mathrm{Ru})_{2} \mathrm{~B}_{3} \mathrm{H}_{8}-\left(\mathrm{CS}_{2} \mathrm{H}\right)\right]^{12}, \mathbf{1}$ with various alkynes. Herein, we describe the syntheses, structures and bonding of some unique ruthenium boryl borylene and boryl complexes.

\section{RESULTS AND DISCUSSION}

\section{Hydroboration of phenyl acetylene using arachno- $\left[\left(\mathrm{Cp}^{*} \mathrm{Ru}\right)_{2} \mathrm{~B}_{3} \mathrm{H}_{8}\left(\mathrm{CS}_{2} \mathrm{H}\right)\right], \mathbf{1}$}

Thermolysis of arachno-1 with phenyl acetylene over 56 hours led to the formation of air and moisture sensitive purple solid $\mathbf{2}$ along with known $\mathbf{3} \mathbf{a}-\mathbf{b}^{11 d}$. The reaction also yielded some unstable compounds in very lowyields and as a result, the characterizations of these complexes were not possible. Complex 2 was isolated as 23\% yield and was characterized by multi-nuclear NMR, IR spectroscopy, mass spectrometry and X-ray diffraction study. The ${ }^{11} \mathrm{~B}\left\{{ }^{1} \mathrm{H}\right\}$ NMR spectrum of 2 showed a broad signal at $\delta=90.4 \mathrm{ppm}$. The ${ }^{1} \mathrm{H}$ NMR spectrum of 2 reveal ed a chemical shift at $\delta=1.36$ ppm which is attributed to the methyl protons associated 
with $\mathrm{Cp}^{*}$ units. The presence of aryl protons and carbon atoms were confirmed from the ${ }^{1} \mathrm{H}$ chemical shifts at $\delta=$

Scheme 1. Reactivity of arachno-ruthenaborane, 1 with phenyl acetylene. $3 a: R=H, R^{\prime}=P h ; 3 b: R=P h, R^{\prime}=H$.

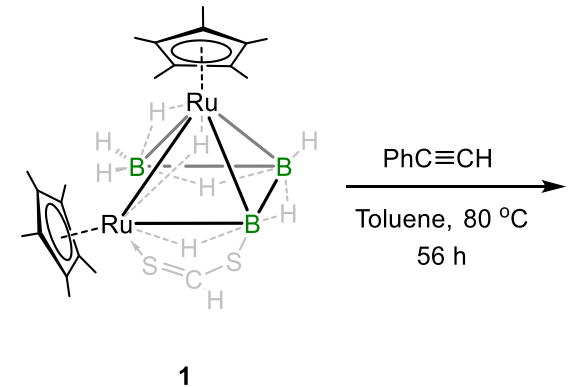

6.52-7.57 ppm and ${ }^{13} \mathrm{C}$ chemical shifts at $\delta=119.8-128.7$ ppm, respectively. Two singlets at $\delta=4.10$ and $3.59 \mathrm{ppm}$, observed in the ${ }^{1} \mathrm{H}$ NMR spectrum of 2 have been assigned to methanedithiolate and another set of methyl protons respectively. The mass spectrometric data of 2 revealed isotopic distribution pattern at $\mathrm{m} / \mathrm{z} 655.0649$ corresponding to the molecular ion $\left\{[\mathrm{M}]^{+}+\mathrm{H}-\mathrm{B}_{2} \mathrm{H}\right\}$.

The single crystal X-ray diffraction analysis was carried out on a suitable crystal of 2 , obtained by slow evaporation of hexane solution at $2^{\circ} \mathrm{C}$. The solid-state X-ray structure of 2, shown in Figure $1(\mathrm{a})$, shows the structure as $\left[\left(\mathrm{Cp}^{*} \mathrm{Ru}\right)_{2}(\mu\right.$ $\left.\left.\mathrm{HBS}_{2} \mathrm{CH}_{2}-\kappa^{2} B: \kappa^{2} S\right)\left\{\mu-\mathrm{B}\left(\mathrm{C}_{6} \mathrm{H}_{4}\right) \mathrm{C}(\mathrm{Me})-\kappa^{2} B: \kappa^{2} C\right\}\right]$, in which a

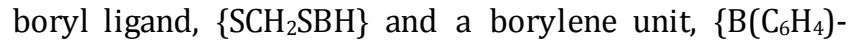
$\mathrm{C}(\mathrm{Me})\}$ bridged two ruthenium centers in $\left\{\mu, \kappa^{2}: \kappa^{2}\right\}$ fashion. Although compound $\mathbf{2}$ has two boron environments, the ${ }^{11} \mathrm{~B}\left\{{ }^{1} \mathrm{H}\right\}$ NMR spectrum shows only one signal at $\delta=90.4$ ppm, which has been assigned to the borylene boron atom based on the similar chemical shift observed for transition metal borylene complexes along with the ${ }^{1} \mathrm{H}-11 \mathrm{~B}\left\{{ }^{1} \mathrm{H}\right\}$ HSQC NMR data and theoretical NMR calculation (Figure S5 and Table S2). ${ }^{13}$ Note that, we did not observe any signal corresponding to the boryl boron in ${ }^{11} \mathrm{~B}\left\{{ }^{1} \mathrm{H}\right\}$ NMR spectrum. However, the DFT calculation predicted the ${ }^{11} \mathrm{~B}$ chemical shift for the boryl boron for 2 at $\delta=70.6 \mathrm{ppm}$. This calculated value is comparable to the ${ }^{11} \mathrm{~B}$ signals of the two boryl groups in 4 (65.9 \& $50.9 \mathrm{ppm})$, but is very different from that of $7(27.7 \mathrm{ppm})$. The ${ }^{11} \mathrm{~B}\left\{{ }^{1} \mathrm{H}\right\}$ chemical shift at $\delta=$ $90.4 \mathrm{ppm}$ is due to the borylene boron which does not associate with any hydrogen. Therefore, any correlation between the $\delta_{\mathrm{B}}=90.4 \mathrm{ppm}$ and $\delta_{\mathrm{H}}=8.70 \mathrm{ppm}$ has not been observed in the ${ }^{1} \mathrm{H}-{ }^{11} \mathrm{~B}\left\{{ }^{1} \mathrm{H}\right\}$ HSQC NMR spectrum. The ${ }^{1} \mathrm{H}-$ ${ }^{11} \mathrm{~B}\left\{{ }^{1} \mathrm{H}\right\}$ HSQC NMR spectrum is an indirect evidence that the ${ }^{11} \mathrm{~B}$ chemical shift at $\delta_{\mathrm{B}}=90.4 \mathrm{ppm}$ is due to borylene boron.

The Ru-B1 distances (1.93(3) and $2.137 \AA$ ) are comparable to that of ruthenium $\mu$-borylene complex $\left[(\mathrm{Cp} * \mathrm{Ru})_{2}(\mu-\mathrm{H})_{2}\left(\mathrm{BC}_{6} \mathrm{Me}_{4} \mathrm{H}\right)\right]^{13 \mathrm{a}}(2.047(4)$ and $2.049(4) \AA)$. In contrast, the Ru-B2 distances $(2.174(15)$ and 2.195(15) $\AA$ ) are reasonably shorter as compared to boryl complex $\left[\left(\mathrm{Cp}^{*} \mathrm{Ru}\right)_{2}(\mu\right.$-H $)(\mu$-CO) $(\mu$-BCat $)],{ }^{14}(2.26 \AA)$ however, similar to that of $\left[\left(\mathrm{Cp}^{*} \mathrm{Ru}\right)_{2}\left(\mu-\mathrm{HBS}_{2} \mathrm{CH}_{2}-\kappa^{2} B: \kappa^{2} S\right)_{2}\right]^{15}(2.197 \AA)$. These dissimilar Ru-B bond lengths (Ru-B1 vs Ru-B2) indicate the presence of different boron centers in 2 . Complex $\mathbf{2}$ is a rare diruthenium complex that feature both the borylene and boryl unit. Gem-diborene species, $\left[(\mathrm{Br}) \mathrm{B}\left\{\left(\mathrm{C}_{6} \mathrm{H}_{4} \mathrm{CH}_{2}\right) \mathrm{PCy}\right\}-\mathrm{B}\left(\mathrm{PMe}_{3}\right)\right]$ may be considered as one of such species in which both boryl and borylene units are present. ${ }^{16}$

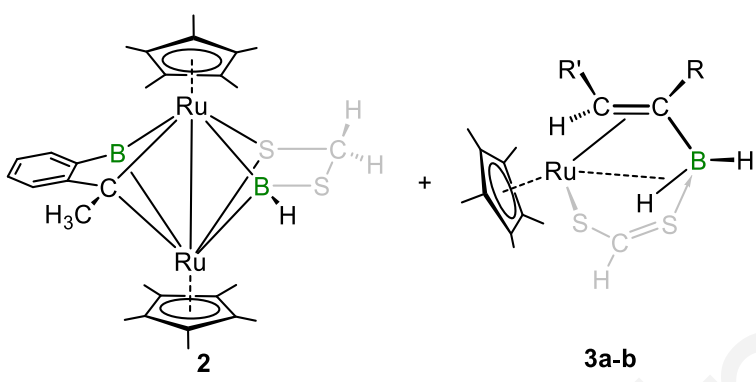

It is reasonable to assume that four acute bite angles ( $\angle \mathrm{Ru} 1-\mathrm{B} 1-\mathrm{Ru}$ 1 $\left(74.21^{\circ}\right), \angle \mathrm{Ru} 1-\mathrm{B} 2-\mathrm{Ru} \_1\left(68.5(5)^{\circ}\right), \angle \mathrm{Ru} 1-$ $\mathrm{S} 2-\mathrm{Ru} \_1\left(61.04^{\circ}\right)$ and $\left.\angle \mathrm{Ru} 1-\mathrm{C} 14-\mathrm{Ru} \_1\left(74.88^{\circ}\right)\right)$ bring the $\mathrm{Ru}$ centers to close proximity that resulted in a shorter $\mathrm{Ru}-$ Ru contact $(2.4607(10) \AA)$ as compared to that in arachno$1(2.9738(3) \AA) .{ }^{12}$ Note that, a Ru-Ru single bond in $\mathbf{2}$ is inferred according to the effective atomic number (EAN) rule. From the solid-state structure of 2 , it is very clear that the $\{-\mathrm{C} \equiv \mathrm{CH}\}$ unit of phenyl acetylene underwent hydroboration to generate $\left\{-\mathrm{C}-\mathrm{CH}_{3}\right\}$ unit, in which the $\mathrm{C} 14$ C16 distance of 1.526(19) $\AA$ falls within the carbon-carbon single bond distance. ${ }^{11 \mathrm{~d}}$ The B1-C11 bond distance of 1.575(19) $\AA$ is comparable to the unperturbed B-C bond distance, signifying the single bond character. ${ }^{15}$ Note that, structurally characterized known metal bridging-boryl complexes are very few since after the appearance of first X-ray structure of such complexes in 1990. ${ }^{\text {a }}$ In that context, complex $\mathbf{2}$ is interesting as the structure is simple and does not require any bulky ligand attached to the boron atom to stabilize the system.

The chemistry of transition metal-boryl complexes has been practised to understand the electronic and steric properties of boryl ligands and their influence on the reaction processes. Further, the involvement of group 9 metal-boryl complexes in metal-catalysed hydroboration were established and recent progress is mostly centred on the utilisation of boryl systems in the catalysis of diboration and $\mathrm{C}-\mathrm{H}$ functionalization processes. ${ }^{7}$ An outstanding growth in metal-boryl complexes has been achieved by catalysis based on precious heavy metals. Often, Rh- and Irbased boryl complexes are used as catalysts and remain the most

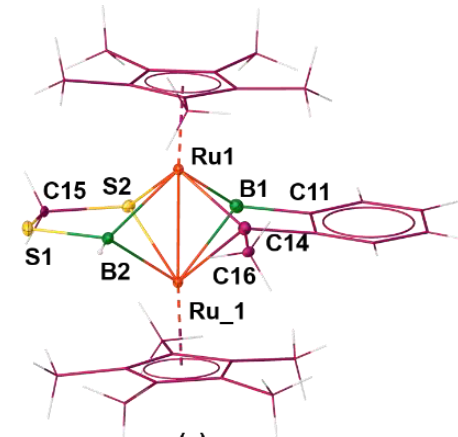

(a)

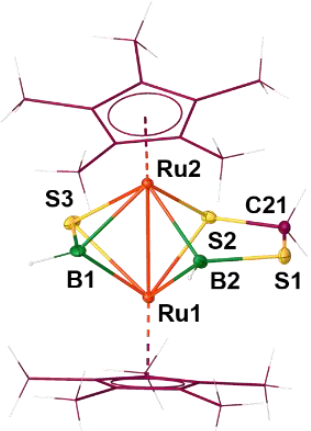

(b)
Figure 1. Molecular structure and labelling diagram of 2 (a) and 4 (b): Selected bond lengths $(\AA)$ and angles $\left({ }^{\circ}\right)$ are: 2: C16C14 1.526(19), B1-C11 1.575(19), C15-S1 1.73(2), C15-S2 
1.822(17), Ru_1-S2 2.401(3), Ru_1-B2 2.195(15), Ru1-B2 2.174(15), Ru1-B1 1.93(3), Ru_1-B1 2.137, S1-B2 1.852(17), $\mathrm{Ru} 1-\mathrm{Ru}$ 1 2.4607(10); $\mathrm{Ru} 1-\mathrm{B} 2-\mathrm{Ru} \_1 \quad 68.5(5) ; \quad 4: \mathrm{Ru} 1-\mathrm{B} 1$ 2.111(13), Ru1-Ru2 2.6388(10), Ru1-B2 2.188(10), Ru2-B1 2.129(12), Ru2-B2 2.180(10), C21-S1 1.781(10), C21-S2 1.790(9), B1-S3 1.798(13), B2-S1 1.849(11); Ru2-S2-Ru1 67.94(7), Ru1-S3-Ru2 66.56(6), Ru1-B1-Ru2 77.0(4).

frequently employed catalysts for such transformations. ${ }^{8}$ In particular, the metal-catalyzed borylation of arenes produces functionalized arenes with regioselectivity that is typically determined by steric factors. This process does not require a chelating substituent to trigger catalyst activity.7 Although complex $\mathbf{2}$ does notshow any cataly tic borylation, intramolecular borylation of the $\mathrm{C}-\mathrm{H}$ bond of the arene ring is quite unique. In most of the cases, borylation of $\mathrm{C}-\mathrm{H}$ bonds in arenes occurs by a different pathway in which the $\mathrm{C}-\mathrm{H}$ bond is cleaved by orthometallation. ${ }^{7}$ In this regard, complex $\mathbf{2}$ is a notable example where the $\mathrm{C}-\mathrm{H}$ borylation occurred. We believe that, the $\mathrm{CCH}_{3}$ moiety is formed via insertion of the alkyne moiety into transiently generated $\mathrm{Ru}-\mathrm{H}$ bonds. In order to trace the source of hydrogens in the methyl group of $\left\{\mathrm{B}\left(\mathrm{C}_{6} \mathrm{H}_{4}\right) \mathrm{C}(\mathrm{Me})\right\}$ unit in $\mathbf{2}$ and to get an insight on the formation of this boryl complex, hydroboration of $\mathbf{1}$ with deuterium labelled phenyl acetylene was carried out. The ${ }^{1} \mathrm{H}$ and ${ }^{2} \mathrm{H}$ NMR spectra evidently demonstrate that one of the hydrogens of methyl unit in the hydroborated complex $\left(2^{D}\right)$ is replaced by deuterium (Scheme S1, Figures S22 and S23) which confirms the possible source of one of the hydrogens in $\left\{\mathrm{CCH}_{3}\right\}$ unit in $\mathbf{2}$ is the reactant alkyne. We also have tested the reactivity of $\mathbf{1}$ with other alkynes such as methyl propiolate, dimethyl acetylenedicarboxylate, cyclohexyl acetylene that led to either decomposition of the starting material or afforded no results. Although, we do not have any experimental evidences, looking at the structure of $\mathbf{2}$ it is reasonable to assume that $\mathbf{2}$ might have formed via insertion of the $\mathrm{C} \equiv \mathrm{C}$ bond into transiently generated $\mathrm{Ru}-\mathrm{H}$ bonds followed by the borylation of the arene unit.

To gain further insight into the bonding of the boryl borylene species $\mathbf{2}$, computational studies were performed at the pbe1pbe/ def2-tzvp level of theory using DFT methods. 17-20 The optimized structure of $\mathbf{2}$ is in well agreement with its solid-state structure. The molecular orbital (MO) analysis of 2 reveals a large HOMO-LUMO gap of $3.234 \mathrm{eV}$. Based on MO analysis, it is evident that the HOMO of 2 shows the overlap of $p$ orbitals of the boron atoms with the $d$ orbitals of both Ru atoms (Figure 2(a)). Whereas, the HOMO-11 reveals the overlap of the donut like ring face of the $d_{\mathrm{z}}{ }^{2}$ orbitals of both Ru centers signifying strong bonding interaction between two Ru atoms (Figure 2(b)). Furthermore, the Wiberg bond index (WBI) of 0.3753 between $\mathrm{Ru}$ centers validates the $\mathrm{Ru}-\mathrm{Ru}$ bonding interaction. ${ }^{21}$ The natural charge analysis also shows that the $\mathrm{B}$ atoms act as donor, whereas the $\mathrm{Ru}$ atoms act as acceptor (Table S1). In addition, the Laplacian electron density plot of 2 reveals the bonding scenario of the plane perpendicular to the Ru-Ru bond. As shown in Figure 2(c), an area of charge concentration along the $\mathrm{C} 16-\mathrm{C} 14$ bond is very prominent. The calculated C14-C16 bond length of $1.505 \AA$ (exp. 1.534(17) Å) indicates the presence of a single bond. The WBI value of 1.0433 between C16 and C14 atoms also indicates single bond interaction, which is further supported by NBO analysis (Figure S29).

\section{Bimetallic bridging bis(boryl) complex, $\left[(\mathrm{Cp} * \mathrm{Ru})_{2}(\mu\right.$ - $\left.\left.\mathrm{HBS}_{2} \mathrm{CH}_{2}-\kappa^{2} \mathrm{~B}: \kappa^{2} S\right)\left\{\mu, \eta^{2}: \eta^{2}-\mathrm{SBH}\right\}\right], 4$}

The formation of bridging boryl borylene species, $\mathbf{2}$ from the reaction of $\mathbf{1}$ with alkyne was somewhat unusual, specially the hydroboration of alkyne and $\mathrm{C}-\mathrm{H}$ borylation of

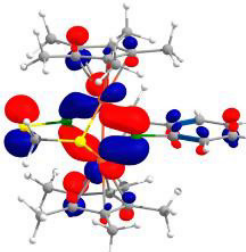

(a)

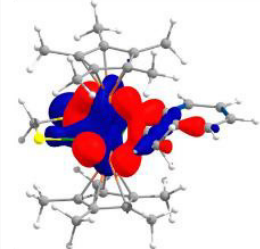

(b)

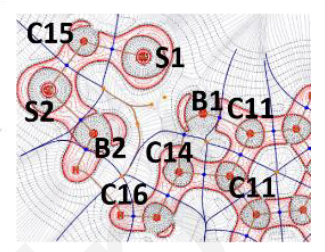

(c)
Figure 2. (a) HOMO and (b) HOMO-11 of the boryl borylene species 2. (c) Laplacian electron density plot of the plane perpendicular to $\mathrm{Ru}-\mathrm{Ru}$ bond; Solid red lines indicate areas of charge concentration $\left(\nabla^{2} \rho(r)<0\right)$, while dashed black lines show areas of charge depletion $\left(\nabla^{2} \rho(r)>0\right)$. Blue dots indicate bond critical points (BCPs)].

the arene ring. From the solid-state X-ray structures of $\mathbf{2}$ and $\mathbf{1}$, it is apparent that they are structurally related as the former (2) is a derivation from the latter (1) and both the species contain $\left\{(\mathrm{Cp} * \mathrm{Ru})_{2}\right\}$ and $\left\{\mathrm{S}_{2} \mathrm{CBH}\right\}$ units. Also, we believe that there must be an intermediate which reacts with the alkyne to produce the hydroborated species 2 . Thus, we carried out the thermolysis of $\mathbf{1}$ in toluene with and without alkyne. The reaction without alkyne led to the formation of orange $\mathbf{4}$ and green $\mathbf{5}$ in 17 and 10\% yields respectively. Both the complexes were separated by thin layer chromatography using hexane $/ \mathrm{CH}_{2} \mathrm{Cl}_{2}$ (80:20) as eluents. They have been characterized by multi-nuclear NMR, IR spectroscopy, mass spectrometry and X-ray diffraction studies.

The ${ }^{11} \mathrm{~B}\left\{{ }^{1} \mathrm{H}\right\}$ NMR spectrum of 4 showed two resonances at $\delta=65.9$ and $50.9 \mathrm{ppm}$ which are upfield shifted as compared to 2 . The presence of $\mathrm{Cp}^{*}$ ligand in $\mathbf{4}$ was confirmed from the ${ }^{1} \mathrm{H}$ chemical shift at $\delta=1.73 \mathrm{ppm}$. This was further supported by the ${ }^{13} \mathrm{C}\left\{{ }^{1} \mathrm{H}\right\}$ NMR spectrum. The ${ }^{1} \mathrm{H}$ NMR spectrum also showed a resonance at $\delta=6.24 \mathrm{ppm}$ that is due to the presence of $\mathrm{BH}_{\mathrm{t}}$ proton/s. The mass spectrometric analysis of $\mathbf{4}$ showed an ionized peak at $m / z$ $=596.0003$ corresponding to $\left\{[\mathrm{M}]^{+}+\mathrm{H}-\mathrm{BH}\right\}$. Suitable crystals for 4 were obtained by the slow evaporation of a hexane $/ \mathrm{CH}_{2} \mathrm{Cl}_{2}(80: 20)$ solution at $2{ }^{\circ} \mathrm{C}$ that allowed us to perform the X-ray diffraction study.

The solid-state X-ray structure of $\mathbf{4}$, shown in Figure 1 (b), reveals the structure of $\mathbf{4}$ as a bridging bis(boryl) complex of ruthenium. Two of the boryl units, $\{\mathrm{HBS}\}$ and $\left\{\mathrm{HBSCH}_{2} \mathrm{~S}\right\}$ are attached perpendicular to $\{\mathrm{Cp} * \mathrm{Ru}\}$ units in $\left(\mu-\kappa^{2}: \kappa^{2}\right)$ fashion and the boron atoms reside on the same face unlike in 2 . The avg. B-S bond distance of $1.824 \AA$ is in accord with the sum of the covalent radii of $\mathrm{B}$ and $\mathrm{S}$ however, shorter as compared to $\left[(\mathrm{Cp} * \mathrm{Ru})_{2}\left(\mu-\mathrm{HBS}_{2} \mathrm{CH}_{2^{-}}\right.\right.$ $\left.\left.\kappa^{2} B: \kappa^{2} S\right)_{2}\right](1.7885 \AA) .{ }^{15}$ Similarly, the avg. C-S bond distance of $1.785 \AA$ in methanedithiolate unit of 4 is within the single bond distance. ${ }^{22,23}$ The ${ }^{1} \mathrm{H}$ chemical shift at $\delta=2.84 \mathrm{ppm}$ and a resonance at $\delta=40.3 \mathrm{ppm}$ in ${ }^{13} \mathrm{C}\left\{{ }^{1} \mathrm{H}\right\}$ NMR spectrum confirms the presence of methanedithiolate ligand in 4 . The $\mathrm{Ru}-\mathrm{Ru}$ bond distance of 2.6388(10) $\AA$ in $\mathbf{4}$ is significantly shorter as compared to the ruthenium oxo-boryl species 
$\left[\{\mathrm{Cp} * \mathrm{Ru}(\mu-\mathrm{H})\}_{3}\left(\mu_{3}-\mathrm{BO}\right)\left(\mu_{3}-\mathrm{H}\right)\right] \quad\left(\operatorname{avg} . \quad 2.7162 \quad \AA\right.$ ). ${ }^{24}$ This shortening of bond length may be due to the presence of two bridging $\mathrm{S}$ atoms that bring the two ruthenium centers closer forming acute angles with them. The average Ru-B bond distance of $2.152 \AA$ is comparatively shorter as compared to $\left[\left\{\mathrm{Cp}^{*} \mathrm{Ru}\left(\mu-\mathrm{HBS}_{2} \mathrm{CH}_{2}-\kappa^{2} B: \kappa^{2} S\right)\right\}_{2}\right]^{15}(2.185 \AA)$. The shorter Ru-S bond lengths in $\left\{\mathrm{HBSCH}_{2} \mathrm{~S}\right\}$ unit compared to

\section{Scheme 2. Thermolysis of arachno-ruthenaborane, $\left[(C p * R u)_{2} B_{3} H_{8}\left(C S_{2} H\right)\right], 1$.}

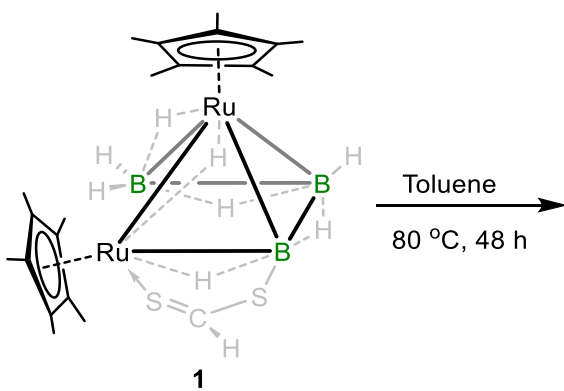

that of $\{\mathrm{HBS}\}$ unit in $\mathbf{4}$ suggests that the sulfur atom of former approaches the ruthenium centers more closely as compared to that of latter. Whereas, the boron atom of the \{HBS\} unit approaches the ruthenium centers more closely as compared to $\left\{\mathrm{HBSCH}_{2} \mathrm{~S}\right\}$ unit.

Although it seemed that the boryl species $\mathbf{4}$ is the intermediate for the formation of $\mathbf{2}$, reaction of $\mathbf{4}$ with phenyl acetylene yielded no traces of $\mathbf{2}$. Nonetheless, the availability of this boryl species $\mathbf{4}$ allowed us to compare its bonding and electronic structure with other diruthenaboryl species with the aid of computational studies. The MO analysis reveals that the HOMO-LUMO gap of $4(4.27 \mathrm{eV})$ is reasonably larger as compared to that of $\mathbf{2}$. Further, the $\mathrm{Ru}-$ $\mathrm{Ru}$ bonding interaction of $\mathbf{4}$ is depicted in HOMO-3 where the donut like ring face of the $d_{\mathrm{z}}^{2}$ orbitals are overlapped (Figure 3(a)). The Ru-Ru bonding interaction is further verified by WBI $(0.3754)$ and Laplacian electron density plot (Figure 3(b)). The coval ent character of Ru1-Ru2 bond has also been reflected by the positive value of electron density $\left(\rho_{\mathrm{b}}=0.0681\right)$ and a negative value of the energy density $[H(r)=-0.0205]$ at bcp. Although the natural charges at both the Ru centers (acceptor) of $\mathbf{4}$ is comparable with that of $\mathbf{2}$, the natural charges at $\mathrm{B}$ atom of the borylene unit of $\mathbf{2}$ is significantly higher as compared to boryl borons in $\mathbf{2}$ and $\mathbf{4}$ (Table S1).

Along with the formation of $\mathbf{4}$, compound $\mathbf{5}$ was isolated as green solid. The ${ }^{1} \mathrm{H}$ NMR spectrum of $\mathbf{5}$ showed two chemical shifts at $\delta=1.68$ and $1.60 \mathrm{ppm}$ due to the methyl protons of $\mathrm{Cp}^{*}$ ligands. Further, the presence of boron was confirmed by ${ }^{11} \mathrm{~B}$ chemical shift, appeared at $\delta=13.5 \mathrm{ppm}$. The mass spectrometric analysis revealed an isotropic distribution pattern at $\left.m / z 566.0492\left\{[\mathrm{M}]^{+}+\mathrm{H}-\mathrm{BH}\right]\right\}$.

The X-ray diffraction studies, performed on a single crystal of 5, obtained from slow evaporation of hexane $/ \mathrm{CH}_{2} \mathrm{Cl}_{2}$ (70:30) solution of $\mathbf{5}$ at $2{ }^{\circ} \mathrm{C}$, revealed its identity as nido-[(Cp* Ru $\left.)_{2}(\mathrm{Me})\left(\mathrm{S}_{2} \mathrm{~B}_{2} \mathrm{H}_{3}\right)\right]$. The solid-state $\mathrm{X}$ ray structure of nido-5, shown in Figure 4(a), clearly

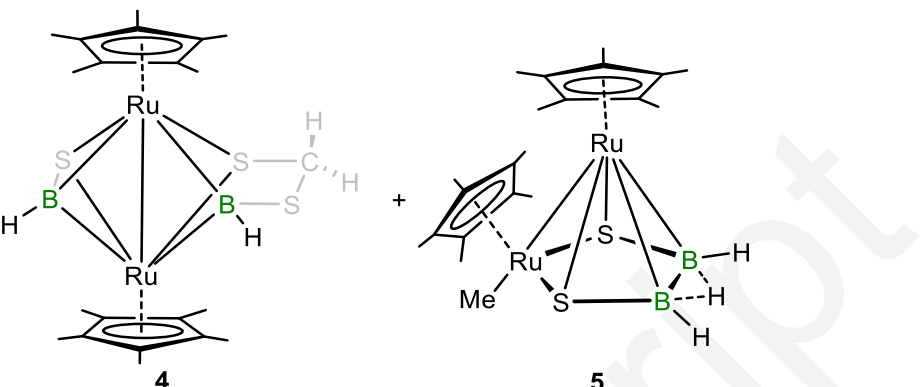

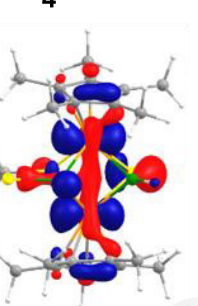

(a)

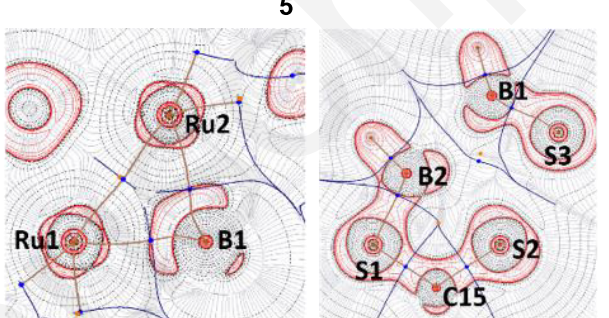

(b) (c)
Figure 3. (a) HOMO-3 of 4; (b) and (c) Laplacian electron density plot of $\mathbf{4}$ of plane (Ru1-B1-Ru2) and plane perpendicular to $\mathrm{Ru}-\mathrm{Ru}$ bond, respectively.

displays a $\left\{\mathrm{S}_{2} \mathrm{~B}_{2} \mathrm{H}_{3}\right\}$ unit, attached to two $\{\mathrm{Cp} * \mathrm{Ru}\}$ units. The $\mathrm{Ru}$-Ru bond distance of 2.878(2) $\AA$ is considerably shorter as compared to ruthenaborane species, $\left[(\mathrm{Cp} * \mathrm{Ru})_{2}\left(\mathrm{~B}_{3} \mathrm{H}_{9}\right)\right]^{25}$ (2.9689(17) Å). The B-S bond distance of 1.87(2) $\AA$ is in agreement with the sum of the covalent radii of $B$ and $S$ atoms. ${ }^{15}$ The molecular structure of $\mathbf{5}$ can be considered as a dimetallaheteroborane analogue of nido- $\left[\mathrm{B}_{6} \mathrm{H}_{10}\right]$, in which one apical $\mathrm{BH}$ and one basal $\mathrm{BH}$ atom is subrogated by $\{\mathrm{Cp} * \mathrm{Ru}\}$ and $\left\{\mathrm{Cp}^{*} \mathrm{RuMe}\right\}$ fragments respectively and other two basal $\mathrm{BH}$ units are subrogated by two $\mathrm{S}$ atoms. The core of $\mathbf{5}$ is similar with ruthenaborane, $\left[(\mathrm{Cp} * \mathrm{Ru})_{2}(\mu-\right.$ $\left.\mathrm{H})_{2}\left(\mathrm{~S}_{2} \mathrm{~B}_{2} \mathrm{H}_{4}\right)\right]^{26}$. Note that one methyl group is attached to one of the $\mathrm{Ru}$ atoms in $\mathbf{5}$ and the chemical shift for this methyl protons appeared at $\delta=-0.20 \mathrm{ppm}$ in ${ }^{1} \mathrm{H}$ NMR spectrum. The bridging hydrogens as well as terminal hydrogens associated with boron atoms were located crystallographically. They were further confirmed by ${ }^{1} \mathrm{H}$ NMR that shows resonances at $\delta=3.50,3.12$ and $-4.44 \mathrm{ppm}$, which are attributed to two $\mathrm{BH}_{\mathrm{t}}$ and one $\mathrm{B}-\mathrm{H}-\mathrm{B}$ proton/s respectively. If one considers that $\{\mathrm{Cp} * \mathrm{Ru}\},\left\{\mathrm{B}_{2} \mathrm{H}_{3}\right\},\left(\mu_{3}-\mathrm{S}\right)$ and (Me) unit contribute 1, 5, 4 and 1 electrons to the cluster bonding framework respectively, ${ }^{27}$ then $\mathbf{5}$ possesses eight skeletal electron pairs (SEP), one SEP lesser than $\left[(\mathrm{Cp} * \mathrm{Ru})_{2}(\mu-\mathrm{H})_{2}\left(\mathrm{~S}_{2} \mathrm{~B}_{2} \mathrm{H}_{2}\right)\right]^{26}$. Therefore, nido-5 is considered as electronically unsaturated species and may be potential to react with electron rich species. As shown in Figure 4(b), nido-5 is analogous to nido- $\left[\mathrm{B}_{6} \mathrm{H}_{10}\right]$ and structurally similar with organometallic analogue $\left[(\mathrm{Cp}+\mathrm{Ru})_{2} \mathrm{~S}_{2} \mathrm{C}_{2} \mathrm{Ph}_{2}\right] .{ }^{28}$ The $\left\{\mathrm{B}_{2} \mathrm{H}_{3}\right\}$ unit of nido-5 provides 5 skel eton electrons for 


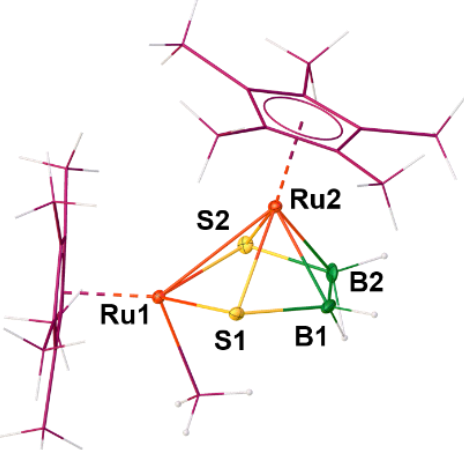

(a)

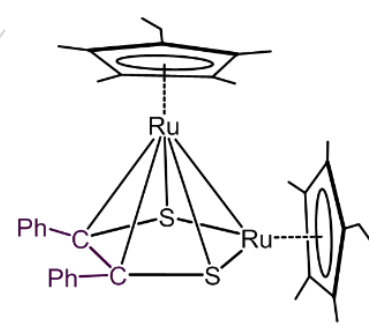

(b)
Figure 4. (a) Molecular structure and labelling diagram of 5: Selected bond length $(\AA)$ and angles $\left({ }^{\circ}\right)$ are: Ru1-B1 2.111(13), Ru1-B2 2.188(10), Ru2-B1 2.129(12), Ru2-B2 2.180(10), Ru1Ru2 2.6388(10), Ru1-S2 2.365(3), C21-S1 1.781(10), C21-S2 1.790(9), B1-S3 1.798(13), B2-S1 1.849(11); S1-C21-S2 113.4(5), Ru1-B1-Ru2 77.0(4).(b) schematic representation of $\left[(\mathrm{Cp}+\mathrm{Ru})_{2} \mathrm{~S}_{2} \mathrm{C}_{2} \mathrm{Ph}_{2}\right]$.
Scheme 3. Synthesis of disulfide complexes of ruthenium

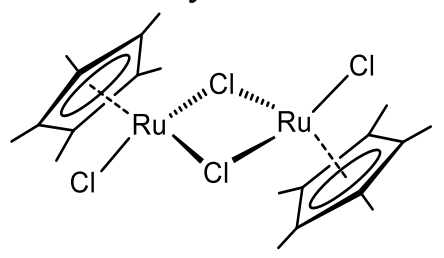

THF, RT, $24 \mathrm{~h}$

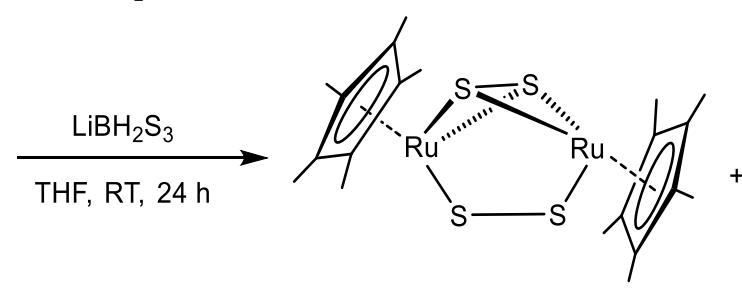

6

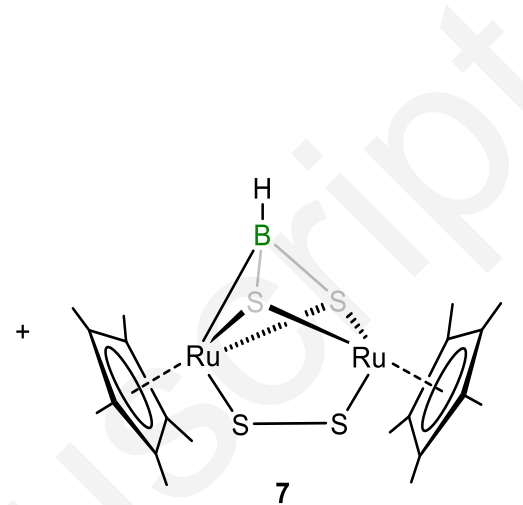

cluster bonding, whereas $\left\{\mathrm{C}_{2} \mathrm{Ph}_{2}\right\}$ moiety of $\left[\left(\mathrm{Cp}^{+} \mathrm{Ru}\right)_{2} \mathrm{~S}_{2}\right.$ $\mathrm{C}_{2} \mathrm{Ph}_{2}$ ] provides 6 skeleton electrons towards the cluster bonding. The missing one skeleton electron of nido-5 is achieved from the exo-polyhedral $\mathrm{CH}_{3}$ group attached to one of the $\mathrm{Ru}$ centers and thus becomes electronically similar with $\left[(\mathrm{Cp}+\mathrm{Ru})_{2} \mathrm{~S}_{2} \mathrm{C}_{2} \mathrm{Ph}_{2}\right]$. As shown in Figure 5, the HOMO-9 of nido-5 reveals the bonding orbitals of $\mathrm{Ru}-\mathrm{CH}_{3}$ bond. From the NBO analysis and Laplacian electron density plot, a high electron density is observed along the B-B and $\mathrm{B}-\mathrm{H}-\mathrm{B}(3 \mathrm{c}-2 \mathrm{e})$ bonds of nido-5 and the $\mathrm{C}-\mathrm{C}$ bond of $\left[\left(\mathrm{Cp}^{+} \mathrm{Ru}\right)_{2} \mathrm{~S}_{2} \mathrm{C}_{2} \mathrm{Ph}_{2}\right]$ (Figures S30-S33). Further, both theoretical and experimental structural parameters of nido5 and $\left[\left(\mathrm{Cp}^{+} \mathrm{Ru}\right)_{2} \mathrm{~S}_{2} \mathrm{C}_{2} \mathrm{Ph}_{2}\right]$ clusters are comparable. Thus, nido-5 can be defined as a true mimic of organometallic cluster nido- $\left[(\mathrm{Cp}+\mathrm{Ru})_{2} \mathrm{~S}_{2} \mathrm{C}_{2} \mathrm{Ph}_{2}\right]$. Note that, besides nido-5, there are several structurally characterized metallaboranes known that mimic classic organometallic clusters. ${ }^{2 b}$

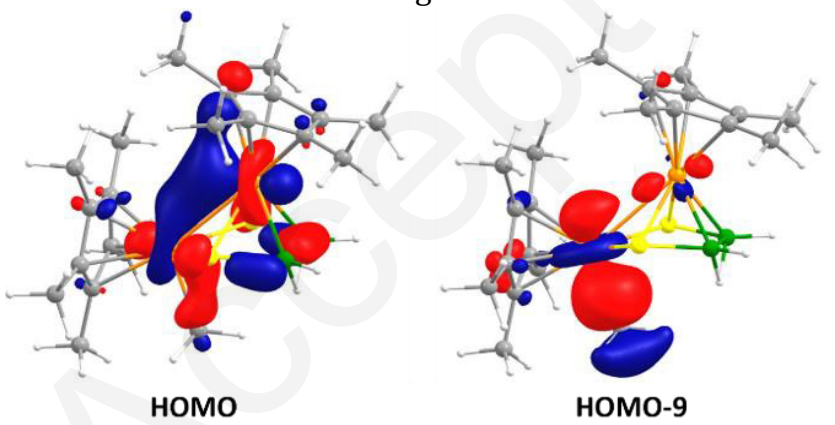

Figure 5. Selected frontier molecular orbitals of nido-5.

\section{Diruthenium boryl complex, 7}

Ruthenium disulfide complex $\left[\left(\mathrm{Cp}^{+} \mathrm{Ru}\right)_{2}\left(\mu, \eta^{1}: \eta^{1-}\right.\right.$ $\left.\left.S_{2}\right)\left(\mu, \eta^{2}: \eta^{2}-S_{2}\right)\right], 28$ made by Rauchfuss etal. in 1999, is a good precursor to synthesize nido- $\left[(\mathrm{Cp}+\mathrm{Ru})_{2} \mathrm{~S}_{2} \mathrm{C}_{2} \mathrm{Ph}_{2}\right]$ when reacted with phenyl acetylene. Interestingly, the $\mathrm{Cp}^{*}$ analogue of this disulfide species, $\left[\left(C p^{*} R u\right)_{2}\left(\mu, \eta^{1}: \eta^{1-}\right.\right.$ $\left.\left.S_{2}\right)\left(\mu, \eta^{2}: \eta^{2}-S_{2}\right)\right], \quad 6$ can also be isolated from the room temperature reaction of $\mathrm{Li}\left[\mathrm{BH}_{2} \mathrm{~S}_{3}\right]$ and $\left[\mathrm{Cp}^{*} \mathrm{RuCl}_{2}\right]_{2}$. Along with the formation of 6 , the reaction also yielded another green complex 7. Both the complexes 6 and 7 were separated using thin layer chromatography with 33 and $19 \%$ yields. Complex 6 was characterized in comparison of its spectroscopic data with $\left[(\mathrm{Cp}+\mathrm{Ru})_{2}\left(\mu, \eta^{1}: \eta^{1}-\mathrm{S}_{2}\right)\left(\mu, \eta^{2}: \eta^{2-}\right.\right.$ $\left.\left.\mathrm{S}_{2}\right)\right],{ }^{28}$ and an X-ray diffraction analysis shows 6 as the $\mathrm{Cp}^{*}$ analogue of $\left[\left(\mathrm{Cp}^{+} \mathrm{Ru}\right)_{2}\left(\mu, \eta^{1}: \eta^{1-} \mathrm{S}_{2}\right)\left(\mu, \eta^{2}: \eta^{2}-\mathrm{S}_{2}\right)\right]^{28}$. The HOMO of 6 displays the donating property through the $p$-orbitals of sulfur atoms and the $d$-orbitals of Ru centers (Figure S27).

Along with the formation of disulfide species 6, complex 7 was isolated. The ${ }^{11} \mathrm{~B}\left\{{ }^{1} \mathrm{H}\right\}$ NMR spectrum shows a signal at $\delta=27.7 \mathrm{ppm}$ that suggests the presence of one boron environment. The chemical shift at $\delta=1.78 \mathrm{ppm}$ in ${ }^{1} \mathrm{H}$ NMR spectrum is due to the presence of $\mathrm{Cp}^{*}$ protons. Presence of terminal hydrogen associated with boron atom was confirmed by ${ }^{1} \mathrm{H}$ NMR spectroscopy $(\delta=6.72 \mathrm{ppm})$. The mass spectrometry (ESI+ mode) showed an intense isotopic distribution pattern at $m / z 612.9529[\mathrm{M}]^{+}$. Nonetheless, all the spectroscopic data along with mass spectrometric data were not adequate enough to predict the molecular structure of 7 . Therefore, the single crystal X-ray diffraction analysis on a suitable crystal of 7 was necessary to reveal its identity.

The solid-state X-ray structure of 7, shown in Figure 6, depicts the structure as diruthenium boryl species, $\left[\left(\mathrm{Cp} \mathrm{p}^{*} \mathrm{Ru}\right)_{2}\left(\mu, \eta^{1}: \eta^{1}-\mathrm{S}_{2}\right)\left(\mu-\mathrm{S}_{2} \mathrm{BH}-\kappa^{1} B: \kappa^{2} S: \kappa^{2} S^{\top}\right)\right]$, in which one boryl ligand $\{\mathrm{SBHS}\}$ is bridged between two $\left\{\mathrm{Cp}^{*} \mathrm{Ru}\right\}$ units in $\left(\mu-\kappa^{1}: \kappa^{2}: \kappa^{2}\right)$ fashion (Table 1). ${ }^{14,15,29}$ Both the ruthenium centers (Ru1 and Ru2) in 7 are in pseudo-octahedral environments. The boryl ligand binds with both the ruthenium centers orthogonally with the $\mathrm{Ru}-\mathrm{S}-\mathrm{Ru}$ angles of 94.78(2) and $94.42(2)^{\circ}$. The Ru-B bond length of 2.284(3) $\AA$ is significantly longer as compared to ruthenium boryl complex $\quad\left[\mathrm{RuH}(\mathrm{CO})\left(\mathrm{PPh}_{3}\right) \quad\left\{\mathrm{B}\left(\mathrm{NCH}_{2} \mathrm{PPh}_{2}\right)_{2} \mathrm{C}_{6} \mathrm{H}_{4}\right\}\right]^{29 \mathrm{c}}$ (2.077(6) $\AA$ ). The avg. Ru-S bond distance of $2.3751 \AA$ in 7 is within the single bond distance as observed in ruthenium dithioformato complex $\left[\left\{\mathrm{Cp}^{*} \mathrm{Ru}\left(\mu, \eta^{3}-\mathrm{SCHS}\right)\right\}_{2}\right]^{15}(2.3733 \AA)$. The S-S bond distance of 1.9985(9) Å is significantly shorter 
than typical disulfide bond $(2.05 \AA)$. The B-S bond distances in 7 (1.809(3) and 1.826(3) $\AA$ ) are within the range of single bond distance as observed in other transition metal-boron species. ${ }^{15,22}$ This type of ruthenium complex stabilized by simple boryl ligand is unique and not many examples of this kind are known.

To understand the bonding situation in 7 , the computational studies have been performed at the pbe1pbe/def2-tzvp level of theory. The HOMO-LUMO

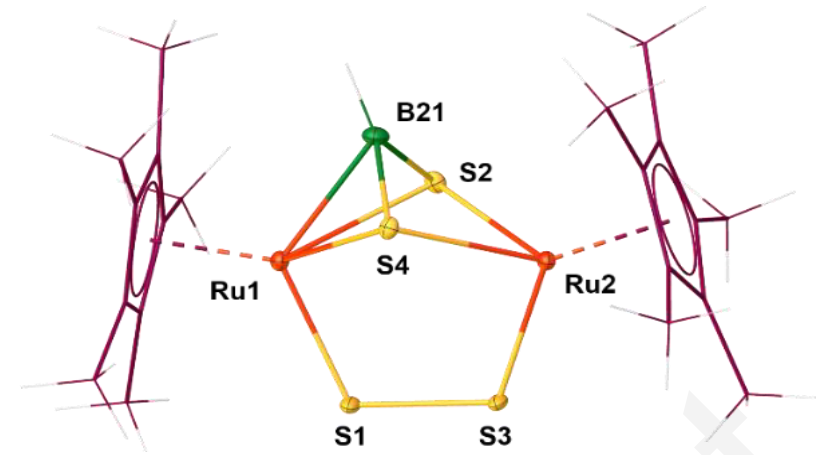

Figure 6. Molecular structure and labelling diagram of 7. Selected bond lengths $(\AA)$ and angles $\left(^{\circ}\right)$ are: Ru 1-S1 2.2599(6), Ru1-B21 2.284(3), Ru1-S4 2.4655(6), Ru2-S3 2.1916(6), Ru2S2 2.4341(6), S1-S3 1.9985(9), B21-S2 1.809(3), B21-S4 1.826(3); S2-B21-S4 105.76(16), S2-B21-Ru1 73.28(10).

Table 1. Selected structural parameters and ${ }^{11} \mathbf{B}$ chemical shifts of ruthenium boryl complexes ${ }^{14,15,29}$

\begin{tabular}{|c|c|c|c|c|c|}
\hline Boryl complexes & $\begin{array}{l}\text { 11B NMR } \\
(\mathrm{ppm})\end{array}$ & $\mathrm{d}(\mathrm{M}-\mathrm{B})(\AA)$ & Complexes & $\begin{array}{l}11 \mathrm{~B} \mathrm{NMR} \\
\text { (ppm) }\end{array}$ & $d(M-B)(\AA ̊)$ \\
\hline Tol & 47.0 & $2.075(4)$ & $=$ & 60.3 & $2.115(2)$ \\
\hline & -28.9 & $2.243(8)$ & & 38.2 & $2.173(3)$ \\
\hline & 61.3 & $2.077(6)$ & & 44.8 & $2.022(4)$ \\
\hline & 53.7 & $2.230(4)$ & & 43.9 & $2.307(6)$ \\
\hline & 110.5 & $2.137(2)$ & & 43.4 & $2.0424(19)$ \\
\hline
\end{tabular}




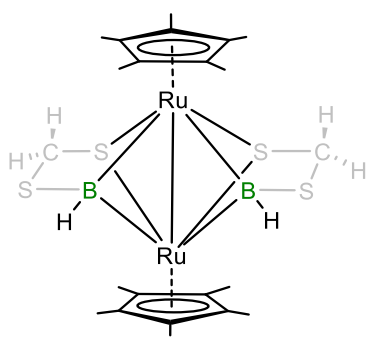

64.1

$2.196(9)$

$2.191(8)$

$2.220(9)$
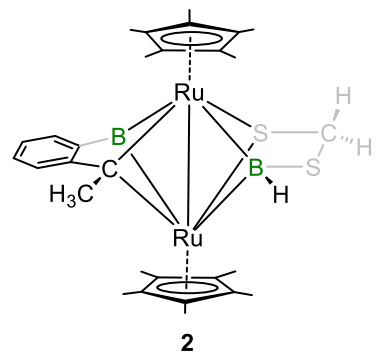

90.4

$1.87(2)$

2.192

$2.111(13)$

$2.188(10)$

65.9

$2.129(12)$

$2.180(10)$
27.7

$2.284(3)$ energy gap for 7 of $2.72 \mathrm{eV}$ is quite smaller as compared to other boryl species 2 and 4. The HOMO-1, HOMO-12 and HOMO-14 of 7 reveal the bonding scenario of the boryl unit with $\mathrm{Ru}$ and $\mathrm{S}$ centers (Figures $7 \mathrm{a}$ and S28). The Laplacian electron density plot along the Ru1-B21-S4 plane of 7 shows high charge concentrations (Figure 7(b)). In addition, the BCPs between Ru-S, Ru-B and B-S bonds clearly indicate strong bonding interactions (Figure 7(b)) The natural charge at $B$ atom of the boryl unit in 7 is negative, whereas for $\mathbf{2}$ and $\mathbf{4}$ the values are positive (Table S1). The negative natural charge of $B$ atom in 7 may be arrived due to the highly positive natural charges of other four sulfur atoms.

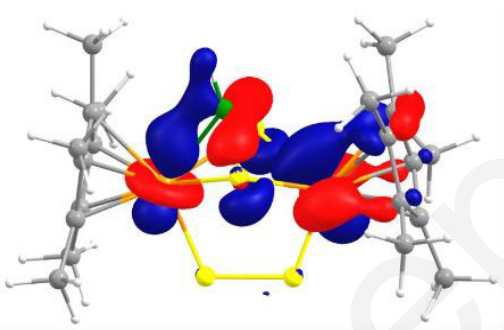

(a)

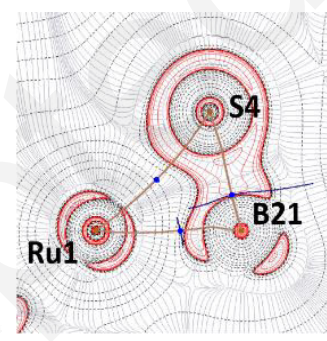

(b)
Figure 7. (a) HOMO-1 of 7. (b) Laplacian electron density plot of 7 along Ru1-B21-S4 plane.

The availability of various structural data for species 2 , $\mathbf{4}$ and $\mathbf{7}$ allowed us to perform a structural comparison with known ruthenium boryl species as listed in Table 1. 14,15,29 In general, the metal center influences the structural parameters of the attached ligands. Therefore, comparing the bond distances between the metal/s and ligand/s in a complex a general conclusion on the role of metal-ligand interaction can be drawn. For example, the $\mathrm{Ru}-\mathrm{B}$ bond distances in 2 (2.1108 $\AA$ ) and $\mathbf{4}(2.152 \AA)$ are within the Ru$B$ single bond distance similar to ruthenium-boryl species, such as $\left[\left\{\mathrm{Cp}^{*} \mathrm{Ru}\left(\mu-\mathrm{HBS}_{2} \mathrm{CH}_{2}-\kappa^{2} B: \kappa^{2} S\right)\right\}_{2}\right]^{15}$ (2.1955 $\AA$ ) and $\left[\left(\mathrm{SiMe}_{3}\right)-\left(\mathrm{PMe}_{3}\right)(\mathrm{CO})_{3} \mathrm{RuB}(\mathrm{Cl})\left(\mathrm{C}_{6} \mathrm{HMe}_{4}\right)\right]^{29 \mathrm{~h}}(2.137(2) \AA)$ (Table 1). However, the Ru-B bond distance of 2.284(3) Å in $\mathbf{7}$ is considerably longer as compared to $\mathbf{2}$ and $\mathbf{4}$. The bridging $\left\{\mathrm{SCH}_{2} \mathrm{~S}\right\}$ ligand in $\mathbf{2}$ and $\mathbf{4}$ may be accountable to keep the boryl units in close proximity with the metal centres.

The ${ }^{11} \mathrm{~B}$ NMR is an important tool for the elucidation of structures of boron complexes. ${ }^{30}$ Thus, to get some insight into the variations in the attachment and bonding of the ligands in these boryl species, we have analyzed the ${ }^{11} \mathrm{~B}$ chemical shift values of the species, listed in Table 1 . The ${ }^{11} \mathrm{~B}$ chemical shift values of the bridging boryl complex 4 are comparable with that of bridging bis(boryl) complex $\left[\left(\mathrm{Cp}^{*} \mathrm{Ru}\right)_{2}\left(\mu-\mathrm{HBS}_{2} \mathrm{CH}_{2}-\kappa^{2} B: K^{2} S\right)_{2}\right] .15$ This may be due to the presence of a similar type of boryl ligand $\left\{\mathrm{HBS}_{2} \mathrm{CH}_{2}\right\}$. On the other hand, the ${ }^{11} \mathrm{~B}$ chemical shift for boryl ligand $\left\{\mu, \eta^{2}: \eta^{2}\right.$ $\mathrm{SBH}\}$ in 4 appeared in the region of 50-65 ppm. Further, the downfield ${ }^{11} \mathrm{~B}$ chemical shift values for $\mathbf{2}$ and $\mathbf{4}$ as compared to 7 may be due to the fact that the boron atom in $\mathbf{7}$ is connected with two sulfur atoms.

\section{CONCLUSION}

In this feature article, we have established some new synthetic routes for different types of bridging borylene and boryl species of ruthenium. Further, we have established the reactivity of arachno-1 with terminal alkyne that generated new type of bridging boryl borylene complex, which is stabilized at the diruthenium template. During the course of formation of bridging boryl borylene complex, the $\mathrm{C}-\mathrm{H}$ bond of arene ring underwent borylation, which is very unusual. Based on the skeleton electron counts and the structures, nido-5 may be considered as analogous to the nido- $\left[\mathrm{B}_{6} \mathrm{H}_{10}\right]$ and $\left[(\mathrm{Cp}+\mathrm{Ru})_{2} \mathrm{~S}_{2} \mathrm{C}_{2} \mathrm{Ph}_{2}\right]$ and it's a true mimic of organometallic counterpart, $\left[(\mathrm{Cp}+\mathrm{Ru})_{2}\left(\mathrm{~S}_{2} \mathrm{C}_{2} \mathrm{Ph}_{2}\right)\right]$. Investigations to evaluate the scope of synthesis of boryl complexes concerning early transition metals are underway.

\section{EXPERIMENTAL SECTION}

I Experimental Details.

General procedures and instrumentation 
All manipulations were conducted under an atmosphere of dry argon or in vacuo using standard Schlenk line or glove box techniques. Solvents (hexane, toluene, thf) were purified by distillation from appropriate drying agents (sodium/ benzophenone) under dry argon prior to use. $\mathrm{CDCl}_{3}$ was degass ed by three freeze-pump-thaw cycles and stored over molecular sieves. $\left[(\mathrm{Cp} * \mathrm{Ru})_{2} \mathrm{~B}_{3} \mathrm{H}_{8}\left(\mathrm{CS}_{2} \mathrm{H}\right)\right],{ }^{12} \mathbf{1}\left[\mathrm{Cp}^{*} \mathrm{RuCl}_{2}\right] 2,{ }^{31}$ and $\mathrm{Li}\left[\mathrm{BH}_{2} \mathrm{~S}_{3}\right],{ }^{32}$ were prepared according to literature methods, while phenyl acetylene was obtained commercially and used as received. Thinlayer chromatography was performed on $250 \mathrm{~mm}$ aluminum supported silica gel TLC plates. NMR spectra were recorded on 400 and $500 \mathrm{MHz}$ Bruker FT-NMR spectrometers. The residual solvent protons were used as reference $\left(\delta, \mathrm{ppm}, \mathrm{CDCl}_{3}, 7.26\right)$, while a sealed tube containing $\left[\mathrm{Bu}_{4} \mathrm{~N}\left(\mathrm{~B}_{3} \mathrm{H}_{8}\right)\right]$ in $\mathrm{d}_{6}$-benzene $\left(\delta_{\mathrm{B}}, \mathrm{ppm},-\right.$ 30.07) was used as an external reference for the ${ }^{11} \mathrm{~B}\left\{{ }^{1} \mathrm{H}\right\}$ NMR. For ${ }^{13} \mathrm{C}\left\{{ }^{1} \mathrm{H}\right\}$ NMR spectra, residual solvent carbon was used as a reference $\left(\delta, \mathrm{ppm}, \mathrm{CDCl}_{3}, 77.1\right)$. Mass spectra were recorded on Qtof Micro YA263 HRMS and 6545 Qtof LC/MS instruments. The infrared spectra were recorded on an Agilent Cary 630 FTIR spectrometer in dichloromethane solvent.

\section{I.1 Synthesis and Characterizations}

Synthesis of 2 and 3a-b: In a flame-dried Schlenk tube, the red solution of $1(0.05 \mathrm{~g}, 0.084 \mathrm{mmol})$ and one equivalent of phenylacetylene in toluene $(20 \mathrm{~mL})$ were stirred at $80{ }^{\circ} \mathrm{C}$ for 56 hours. The solvent was evaporated in vacuum; residue was extracted into hexane/thf $(95: 5 \mathrm{v} / \mathrm{v})$ and passed through celite. After removal of solvent, the residue was subjected to chromatographic work-up using silica gel TLC plates. Elution with hexane yielded purple $2(0.013 \mathrm{~g}, 23 \%)$ and orange solids $\mathbf{3} \mathbf{a}-\mathbf{b}$ $(\sim 18 \%)$.

2: MS (ESI ${ }^{+}$) calcd for $\mathrm{C}_{29} \mathrm{H}_{40} \mathrm{Ru}_{2} \mathrm{~S}_{2}{ }^{+}\left\{[\mathrm{M}]^{+}+\mathrm{H}-\mathrm{B}_{2} \mathrm{H}\right\} \mathrm{m} / z$ 655.0680, found 655.0649; ${ }^{11} \mathrm{~B}\left\{{ }^{1} \mathrm{H}\right\}$ NMR $\left(160 \mathrm{MHz}, \mathrm{CDCl}_{3}, 22^{\circ} \mathrm{C}\right): \delta=90.4(\mathrm{br}$ 1B); ${ }^{1} \mathrm{H}$ NMR (500 MHz, $\left.\mathrm{CDCl}_{3}, 22^{\circ} \mathrm{C}\right): \delta=8.70(\mathrm{br}, 1 \mathrm{H} ; \mathrm{BH}$ ), 7.57$6.52(\mathrm{~m}, 4 \mathrm{H} ; \mathrm{Ph}), 4.10\left(\mathrm{~s}, 2 \mathrm{H} ; \mathrm{CH}_{2} \mathrm{~S}_{2}\right), 3.59\left(\mathrm{~s}, 3 \mathrm{H} ; \mathrm{CH}_{3}\right), 1.36 \mathrm{ppm}(\mathrm{s}$, $\left.30 \mathrm{H} ; 2 \times \mathrm{Cp}^{*}\right) ;{ }^{13} \mathrm{C}\left\{{ }^{1} \mathrm{H}\right\}$ NMR $\left(125 \mathrm{MHz}, \mathrm{CDCl}_{3}, 22{ }^{\circ} \mathrm{C}\right): \delta=143.1$ $\left(\mathrm{CCH}_{3}\right), 128.7-119.8$ (s, Ph), 91.5 (s, $\left.\mathrm{C}_{5} \mathrm{Me} 5\right), 51.5\left(\mathrm{CH}_{2} \mathrm{~S}_{2}\right), 37.3$ $\left(\mathrm{CCH}_{3}\right), 9.5 \mathrm{ppm}\left(\mathrm{s}, \mathrm{C}_{5} \mathrm{Me} 5\right)$; IR $\left(\mathrm{CH}_{2} \mathrm{Cl}_{2}\right) \tilde{v}=2411 \mathrm{~cm}^{-1}\left(\mathrm{BH}_{\mathrm{t}}\right)$.

Synthesis of 4 and 5: In a flame-dried Schlenk tube, the red solution of $1(0.05 \mathrm{~g}, 0.084 \mathrm{mmol})$ in toluene $(20 \mathrm{~mL})$ was stirred at $80{ }^{\circ} \mathrm{C}$ for 48 hours. The solvent was evaporated in vacuum; residue was extracted into hexane $/ \mathrm{CH}_{2} \mathrm{Cl}_{2}(70: 30 \mathrm{v} / \mathrm{v})$ and passed through celite. After removal of solvent, the residue was subjected to chromatographic work-up using silica gel TLC plates. Elution with a hexane $/ \mathrm{CH}_{2} \mathrm{Cl}_{2}(75: 25 \mathrm{v} / \mathrm{v})$ mixture yielded orange $4(0.008$ g, 17\%) and green 5 (0.005 g, 10\%).

4: MS (ESI ${ }^{+}$) calcd for $\mathrm{C}_{21} \mathrm{H}_{34} \mathrm{Ru}_{2} \mathrm{BS}_{3}{ }^{+}\left\{[\mathrm{M}]^{+}+\mathrm{H}-\mathrm{BH}\right\} \mathrm{m} / z$ 596.0025, found 596.0003; ${ }^{11} \mathrm{~B}\left\{{ }^{1} \mathrm{H}\right\}$ NMR $\left(160 \mathrm{MHz}, \mathrm{CDCl}_{3}, 22{ }^{\circ} \mathrm{C}\right): \delta=65.9(\mathrm{br}$, 1B), $50.9 \mathrm{ppm}(\mathrm{br}, 1 \mathrm{~B}) ;{ }^{1} \mathrm{H}$ NMR $\left(500 \mathrm{MHz}, \mathrm{CDCl}_{3}, 22{ }^{\circ} \mathrm{C}\right): \delta=6.24$ (br, 2H; B Ht), $2.84\left(\mathrm{~s}, 2 \mathrm{H} ; \mathrm{CH}_{2} \mathrm{~S} 2\right), 1.73 \mathrm{ppm}\left(\mathrm{s}, 30 \mathrm{H} ; 2 \times \mathrm{Cp}^{*}\right) ;{ }^{13} \mathrm{C}\left\{{ }^{1} \mathrm{H}\right\}$ NMR (100 MHz, $\left.\mathrm{CDCl}_{3}, 22^{\circ} \mathrm{C}\right): \delta=94.0$ (s, $\left.\mathrm{C}_{5} \mathrm{Me}\right), 40.3\left(\mathrm{~s}, \mathrm{CH}_{2} \mathrm{~S}_{2}\right)$, $10.2 \mathrm{ppm}\left(\mathrm{s}, \mathrm{C} 5 \mathrm{Mes}_{5}\right) ; \mathrm{IR}\left(\mathrm{CH}_{2} \mathrm{Cl}_{2}\right) \tilde{v}=2552,2417 \mathrm{~cm}^{-1}\left(\mathrm{BH}_{\mathrm{t}}\right)$.

5: MS $\left(\mathrm{ESI}^{+}\right)$calcd for $\mathrm{C}_{21} \mathrm{H}_{35} \mathrm{Ru}_{2} \mathrm{BS}_{2}{ }^{+}[\mathrm{M}-\mathrm{BH}]^{+} \mathrm{m} / z$ 566.0462, found 566.0492; ${ }^{11} \mathrm{~B}\left\{{ }^{1} \mathrm{H}\right\}$ NMR $\left(160 \mathrm{MHz}, \mathrm{CDCl}_{3}, 22{ }^{\circ} \mathrm{C}\right): \delta=13.5$ ppm (br, 2B); ${ }^{1} \mathrm{H}$ NMR (500 MHz, $\left.\mathrm{CDCl}_{3}, 22{ }^{\circ} \mathrm{C}\right): \delta=3.50,3.12(\mathrm{br}$ $2 \mathrm{H} ; \mathrm{B} H \mathrm{t}), 1.60,1.68\left(\mathrm{~s}, 30 \mathrm{H} ; 2 \times \mathrm{Cp}^{*}\right),-0.20(\mathrm{~s}, 3 \mathrm{H}, \mathrm{CH}),-4.44 \mathrm{ppm}$ (br, $1 \mathrm{H} ; \mathrm{B}-H-\mathrm{B}) ;{ }^{13} \mathrm{C}\left\{{ }^{1} \mathrm{H}\right\}$ NMR $\left(100 \mathrm{MHz}, \mathrm{CDCl}_{3}, 22^{\circ} \mathrm{C}\right): \delta=96.6(\mathrm{~s}$, $\left.C_{5} \mathrm{Me} 5\right), 19.4\left(\mathrm{~s}, \mathrm{CH}_{3}\right), 11.3,10.6 \mathrm{ppm}\left(\mathrm{s}, \mathrm{C}_{5} M e 5\right)$; IR $\left(\mathrm{CH}_{2} \mathrm{Cl}_{2}\right) \tilde{v}=$ 2513(BHt), $2390(\mathrm{BHb}) \mathrm{cm}^{-1}$

Synthesis of 6 and 7: In a flame-dried Schlenk tube, a suspension of [Cp* $\left.\mathrm{RuCl}_{2}\right] 2(0.05 \mathrm{~g}, 0.081 \mathrm{mmol})$ in $10 \mathrm{~mL}$ tetrahydrofuran at $78{ }^{\circ} \mathrm{C}$ was charged dropwise with a freshly prepared solution of $\mathrm{Li}\left[\mathrm{BH}_{2} \mathrm{~S}_{3}\right]$ in tetrahydrofuran $(10 \mathrm{~mL}, 0.324 \mathrm{mmol}, 0.0324 \mathrm{~mol} / \mathrm{L})$ over $15 \mathrm{~min}$ and kept under constant stirring for $24 \mathrm{~h}$ at room temperature. The solvent was evaporated in vacuum; residue was extracted into hexane $/ \mathrm{CH}_{2} \mathrm{Cl}_{2} \quad(60: 40 \mathrm{v} / \mathrm{v})$ and passed through celite. After removal of solvent, the residue was subjected to chromatographic work-up using silica gel TLC plates. Elution with a hexane $/ \mathrm{CH}_{2} \mathrm{Cl}_{2} \quad(80: 20 \mathrm{v} / \mathrm{v})$ mixture yielded blue $6(0.016 \mathrm{~g}, 33 \%)$ and green 7 (0.010 g, 19\%).
6: MS (ESI ${ }^{+}$) calcd for $\mathrm{C}_{20} \mathrm{H}_{30} \mathrm{Ru}_{2} \mathrm{~S}_{4}{ }^{+}[\mathrm{M}]^{+} m / z$ 601.9327, found

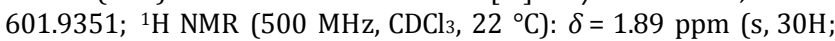
$\left.2 \times \mathrm{Cp}^{*}\right) ;{ }^{13} \mathrm{C}\left\{{ }^{1} \mathrm{H}\right\}$ NMR $\left(100 \mathrm{MHz}, \mathrm{CDCl}_{3}, 22{ }^{\circ} \mathrm{C}\right): \delta=95.3$ (s, $\left.C_{5} \mathrm{Me} 5\right)$, $10.9 \mathrm{ppm}(\mathrm{s}, \mathrm{C} 5 \mathrm{Mes})$.

7: MS $\left(\mathrm{ESI}^{+}\right.$) calcd for $\mathrm{C}_{20} \mathrm{H}_{31} \mathrm{Ru}_{2} \mathrm{~S}_{4} \mathrm{~B}^{+}[\mathrm{M}]^{+} m / z$ 612.9509, found 612.9529; ${ }^{11} \mathrm{~B}\left\{{ }^{1} \mathrm{H}\right\}$ NMR $\left(160 \mathrm{MHz}, \mathrm{CDCl}_{3}, 22{ }^{\circ} \mathrm{C}\right): \delta=27.7 \mathrm{ppm}(\mathrm{br}$, 1B); ${ }^{1} \mathrm{H}$ NMR (500 MHz, $\mathrm{CDCl}_{3}, 22{ }^{\circ} \mathrm{C}$ ): $\delta=6.72(\mathrm{br}, 1 \mathrm{H} ; \mathrm{B} H \mathrm{t}$ ), 1.78

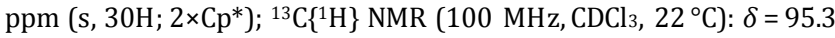
(s, $\left.C_{5} \mathrm{Me}_{5}\right), 10.6 \mathrm{ppm}\left(\mathrm{s}, \mathrm{C}_{5} M e_{5}\right) ; \operatorname{IR}\left(\mathrm{CH}_{2} \mathrm{Cl}_{2}\right) \tilde{v}=2524 \mathrm{~cm}^{-1}\left(\mathrm{BH}_{\mathrm{t}}\right)$.

\section{I.2. X-ray Analysis Details}

Suitable X-ray quality crystals of 2, 4, 5, 6 and 7 were grown by slow diffusion of a hexane- $\mathrm{CH}_{2} \mathrm{Cl}_{2}$ solution. The crystal data for 2,4 and $\mathbf{5}$ were collected and integrated using a Bruker AXS Kappa APEX2 CCD diffractometer with graphite monochromated Mo-Ka $(\lambda=0.71073 \AA)$ radiation at 296(2) K. The crystal data for $\mathbf{6}$ and $\mathbf{7}$ were collected and integrated using a D8 VENTURE Bruker AXS diffractometer with graphite monochromated Mo-K $\alpha(\lambda=0.71073$ $\AA$ ) radiation at $150(2)$ K.The structure of 2 was solved by heavy atom methods using SIR92 and refined using SHELXL-2018/3. ${ }^{33,34}$ The structure of $\mathbf{4}$ was solved by heavy atom methods using SHELXT-2014/5 and refined using SHELXL-2018/3.34 The structure of $\mathbf{5}$ was solved by heavy atom methods using SHELXT 2014/5 and refined using SHELXL-2018/3. ${ }^{34}$ The structure of 6 and 7 were solved by heavy atom methods using SHELXT-2015 and refined using SHELXL-2018/3. ${ }^{34}$ The molecular structures were drawn using Olex ${ }^{2}$ software. ${ }^{35}$ The non-hydrogen atoms were refined with anisotropic displacement parameters. Crystallographic data have been deposited with the Cambridge Crystallographic Data Center as supplementary publication no CCDC-1990065 (2), CCDC-1990066 (4), CCDC-1990067 (5), CCDC1990068 (6) and CCDC-1990069 (7). These data can be obtained free of charge from The Cambridge Crystallographic Data Centre via www.ccdc.cam.ac.uk/data requ est/cif.

Crystal data for 2: $\mathrm{C}_{2} \mathrm{H}_{40} \mathrm{~B}_{2} \mathrm{Ru}_{2} \mathrm{~S}_{2}, M_{r}=676.49$, Tetragonal, space group $I$ 41/a, $a=13.1579(4) \AA, b=13.1579(4) \AA, c=32.8239(16)$ $\AA, \alpha=90^{\circ}, \beta=90^{\circ}, \gamma=90^{\circ}, V=5682.8(4) \AA^{3}, Z=8, \rho_{\text {calcd }}=1.581$ $\mathrm{g} / \mathrm{cm}^{3}, \mu=1.227 \mathrm{~mm}^{-1}, F(000)=2752, R_{1}=0.0470, w R_{2}=0.1030$, 1972 independent reflections $\left[2 \theta \leq 49.976^{\circ}\right]$ and 192 parameters. Crystal data for 4: $\mathrm{C}_{21} \mathrm{H}_{34} \mathrm{~B}_{2} \mathrm{Ru}_{2} \mathrm{~S}_{3}, M_{r}=606.42$, Triclinic, space group $P-1, a=13.9273(5) \AA, b=14.3620(7) \AA, c=14.7096(7) \AA, \alpha$ $=76.888(3)^{\circ}, \beta=64.981(2)^{\circ}, \gamma=64.953(2)^{\circ}, V=2411.37(19) \AA^{3}, Z$ $=4, \rho_{\text {calcd }}=1.670 \mathrm{~g} / \mathrm{cm}^{3}, \mu=1.518 \mathrm{~mm}^{-1}, F(000)=1224, R_{1}=0.0454$, $w R_{2}=0.0830,4236$ independent reflections $\left[2 \theta \leq 49.998^{\circ}\right]$ and 521 parameters.

Crystal data for 5: $\mathrm{C}_{21} \mathrm{H}_{36} \mathrm{~B}_{2} \mathrm{Ru}_{2} \mathrm{~S}_{2}, M_{r}=576.38$, Monoclinic, space group $P 21 / c, a=14.329(4) \AA, b=9.1095(16) \AA, c=19.357(5) \AA, \alpha$ $=90^{\circ}, \beta=105.817(8)^{\circ}, \gamma=90^{\circ}, V=2431.0(10) \AA^{3}, Z=4, \rho_{\text {calcd }}=1.575$ $\mathrm{g} / \mathrm{cm}^{3}, \mu=1.419 \mathrm{~mm}^{-1}, F(000)=1168, R_{1}=0.0932, w R_{2}=0.2001$, 5447 independent reflections $\left[2 \theta \leq 44.204^{\circ}\right]$ and 268 parameters. Crystal data for 6: $\mathrm{C}_{20} \mathrm{H}_{30} \mathrm{Ru}_{2} \mathrm{~S}_{4}, M_{r}=600.82$, Monoclinic, space group $P 21 / c, a=15.2538(14) \AA, b=10.4684(9) \AA, c=15.1172(13)$ $\AA, \alpha=90^{\circ}, \beta=107.016(3)^{\circ}, \gamma=90^{\circ}, V=2308.3(4) \AA^{3}, Z=4, \rho$ calcd $=$ $1.729 \mathrm{~g} / \mathrm{cm}^{3}, \mu=1.673 \mathrm{~mm}^{-1}, F(000)=1208, R_{1}=0.0222, w R_{2}=$ $0.0532,4829$ independent reflections $\left[2 \theta \leq 54.962^{\circ}\right]$ and 245 parameters.

Crystal data for 7: $\mathrm{C}_{20} \mathrm{H}_{31} \mathrm{BRu}_{2} \mathrm{~S}_{4}, M_{r}=612.64$, Monoclinic, space group $P 21 / n, a=7.9142(7) \AA, b=20.1634(19) \AA, c=15.2351(14)$ $\AA, \alpha=90^{\circ}, \beta=100.935(4)^{\circ}, \gamma=90^{\circ}, V=2387.0(4) \AA^{3}, Z=4, \rho_{\text {calcd }}=$ $1.705 \mathrm{~g} / \mathrm{cm}^{3}, \mu=1.619 \mathrm{~mm}^{-1}, F(000)=1232, R_{1}=0.0241, w R_{2}=$ $0.0517,4737$ independent reflections $\left[2 \theta \leq 54.968^{\circ}\right]$ and 257 parameters.

\section{ASSOCIATED CONTENT}

\section{Supporting Information}

The Supporting Information is available free of charge on the ACS Publications website at DOI: xx. It contains ${ }^{1} \mathrm{H},{ }^{11} \mathrm{~B}\left\{{ }^{1} \mathrm{H}\right\}$, ${ }^{13} \mathrm{C}\left\{{ }^{1} \mathrm{H}\right\} \mathrm{NMR}$, mass spectra and X-ray analysis for complexes 2 , 
4, 5, 6 and 7. This material is available free of charge via the internet at http://pubs.acs.org.

\section{AUTHOR INFORMATION}

\section{Corresponding Author}

*E-mail: sghosh@iitm.ac.in. Tel: +91-44-22574230. Fax: +91 44-22574202

\section{Author Contributions}

The manuscript was written through contributions of all authors. All authors have given approval to the final version of the manuscript. ${ }^{\S}$ S. K. and U. K. are equal second authors.

\section{Notes}

The authors declare no competing financial interest.

\section{ACKNOWLEDGMENT}

This work was supported by the Indo-French Center for the Promotion of Advanced Research (IFCPAR-CEFIPRA), Grant No. 5905-1, New Delhi, India. K.S. thanks CSIR, India for the research fellowship. The authors are thankful to Dr. Babu Varghese for the help to solve the X-ray structures.

\section{REFERENCES}

(1) (a) Contemporary Metal Boron Chemistry I. Borylenes, Boryls, Borane $\sigma$-complexes, and Borohydrides. Eds. T. B. Marder, Z. Lin, Struct. Bond. (Berlin), 2008, 130, 1-202. (b) Braunschweig, H.; Kollann, C.; Rais, D. Transition-Metal Complexes of Boron-New Insights and Novel Coordination Modes. Angew. Chem. Int. Ed. 2006, 45, 5254-5274.

(2) (a) Boron Beyond the Icosahedral Barrier: A 16-Vertex Metallaborane: Roy, D. K.; Bose, S. K.; Anju, R. S.; Mondal, B.; Ramkumar, V.; Ghosh, S. Angew. Chem. Int. Ed. 2013, 52, 3222-3226. (b) Ghosh, S.; Noll, B. C. Fehlner, T. P. Borane Mimics of Classic Organometallic Compounds: $\left[(\mathrm{Cp} * \mathrm{Ru}) \mathrm{B}_{8} \mathrm{H}_{14} \quad\left(\mathrm{RuCp}^{*}\right)\right]^{0,+}$, Isoelectronic Analogues of Dinuclear Pentalene Complexes. Angew. Chem. Int. Ed. 2005 , 44, 6568-6571. (c) Bose, S. K.; Geetharani, K.; Varghese, B.; Ghosh, S. Unusual Organic Chemistry of a Metallaborane Substrate: Formation of Tantalaborane Complex with Bridging Acyl Group $\left(\mu, \eta^{2}\right)$. Inorg. Chem. 2010, 49, 63756377.

(3) (a) Borthakur, R.; Saha, K.; Kar, S.; Ghosh, S. Recent advances in transition metal diborane(6), diborane(4) and diborene(2) chemistry. Coord. Chem. Rev. 2019, 399, 213021. (b) Ramalakshmi, R.; Saha, K.; Roy, D. K.; Varghese, B.; Phukan, A. K.; Ghosh, S. New Routes to a Series of $\sigma$ Borane/Borate Complexes of Molybdenum and Ruthenium. Chem. Eur. J. 2015, 21, 17191-17195. (c) Saha, K.; Ramalakshmi, R.; Gomosta, S.; Pathak, K.; Dorcet, V.; Roisnel, T.; Halet, J.-F.; Ghosh, S. Design, Synthesis and Chemistry of Bis( $\sigma$ )borate and Agostic Complexes of Group-7 Metals. Chem. Eur. J. 2017, 23, 9812-9820. (d) Roy, D. K.; Borthakur, R.; Bhattacharyya, S.; Ramkumar, V.; Ghosh, S. Borate-based ligands with soft heterocycles and their ruthenium complexes. J. Organomet. Chem. 2015, 799-800, 132-137. (e) Roy, D. K.; De, A.; Panda, S.; Varghese, B.; Ghosh, S. Chemistry of N,S-heterocyclic Carbene and Metallaboratrane Complexes: A Novel $\eta^{3}$-BCC-Borataallyl Complex. Chem. Eur. J. 2015, 21, 13732-13738.

(4) Brown, H. C.; Rao, B. C. S. A new technique for the conversion of olefins into organoboranes and related alcohols. J. Am. Chem. Soc. 1956, 78, 5694-5695.

(5) (a) Chong, C. C.; Kinjo, R. Catalytic Hydroboration of Carbonyl Derivatives, Imines, and Carbon Dioxide. ACS Catal. 2015, 5, 3238-3259. (b) Obligacion, J. V.; Chirik, P. J. Earth-abundant transition metal catalysts for alkene hydrosilylation and hydroboration. Nat. Rev. Chem. 2018, 2, 15-34.

(6) (a) Männig, D.; Nöth, H. Catalytic Hydroboration with Rhodium Complexes. Angew. Chem. Int. Ed. Engl. 1985, 24, 878-879. (b) Zuo, Z.; Wen, H.; Liu, G.; Huang, Z.; CobaltCatalyzed Hydroboration and Borylation of Alkenes and Alkynes. Synlett. 2018,29, 1421-1429.

(7) Mkhalid, I. A. I.; Barnard, J. H.; Marder, T. B.; Murphy, J. M.; Hartwig, J. F. C-H Activation for the Construction of C-B Bonds. Chem. Rev. 2010, 110, 890-931.

(8) (a) Shoba, V. M.; Thacker, N. C.; Bochat, A. J.; Takacs, J. M. Synthesis of Chiral Tertiary Boronic Esters by OximeDirected Catalytic Asymmetric Hydroboration. Angew. Chem. Int. Ed. 2016, 55, 1465-1469. (b) Mazet, C.; Gerard, D. Highly regio- and enantioselective catalytic asymmetric hydroboration of $\alpha$-substituted styrenyl derivatives. Chem. Commun. 2011, 298-300.

(9) (a) Weiss, R.; Bowser, J. R.; Grimes, R. N. Studies of 2- $\left(\eta^{5}-\right.$ $\left.\mathrm{C}_{5} \mathrm{H}_{5}\right) \mathrm{CoB}_{4} \mathrm{H}_{8}$, a Cobaltaborane Analogue of $\mathrm{B}_{5} \mathrm{H}_{9}$; Inorg. Chem. 1978, 17, 1522-1527. (b) A Mechanistic Study of the Utilization of arachno-Diruthenaborane [(Cp*RuCO $\left.)_{2} \mathrm{~B}_{2} \mathrm{H}_{6}\right]$ as an Active Alkyne-Cyclotrimerization Catalyst. Geetharan $\mathrm{i}$, K.; Tussupbayev, S.; Borowka, J.; Holthausen, M. C.; Ghosh, S. Chem. Eur. J. 2012, 18, 8482-8489. (c) Bose, S. K.; Roy, D. K.; Shankhari, P.; Yuvaraj, K.; Mondal, B.; Sikder, A.; Ghosh, S. Syntheses and Characterization of New Vinyl-Borylene Complexes by the Hydroboration of Alkynes with $\left[\left(\mu_{3}-\right.\right.$ $\left.\mathrm{BH})\left(\mathrm{Cp}^{*} \mathrm{RuCO}\right)_{2}(\mu-\mathrm{CO}) \mathrm{Fe}(\mathrm{CO})_{3}\right]$. Chem. Eur. J. 2013, 19, 23372343.

(10) (a) Yan, H.; Beatty A. M.; Fehlner, T. P. Reactivity of Dimetallapentaboranes nido- $\left[\mathrm{CpM}_{2} \mathrm{~B}_{3} \mathrm{H}_{7}\right]$ with Alkynes: Insertion to Form a Ruthenacarborane $(\mathrm{M}=\mathrm{RuH})$ versus Catalytic Cyclotrimerization to Form Arenes (M=Rh). Angew. Chem. Int. Ed. 2001, 40, 4498-4501. (b) Bould, J.; Rath, N. P.; Barton, L. Metallaborane Heteroatom Incorporation Reactions: Metallacarboranes, Metalla-thiaboranes, and an Iridaazaborane from Iridanonaborane Precursors. Organometallics 1996, 15, 4916-4929.

(11) (a) Anju, R. S.; Mondal, B.; Saha, K.; Panja, S.; Varghese, B. Ghosh, S. Hydroboration of Alkynes with Zwitterionic Ruthenium-Borate Complex: Novel Vinylborane Complexes. Chem. Eur. J. 2015, 21, 11393-11400. (b) Saha, K.; Joseph, B.; Ramalakshmi, R.; Anju, R. S.; Varghese, B.; Ghosh, S. $\eta^{4}$-HBCC$\sigma, \pi$-Borataallyl Complexes of Ruthenium Comprising an Agostic Interaction. Chem. Eur. J. 2016, 22, 7871-7878. (c) Saha, K.; Joseph, B.; Borthakur, R.; Ramalakshmi, R.; Roisnel, T.; Ghosh, S. Chemistry of ruthenium $\sigma$-borane complex, $\left[\mathrm{Cp}^{*} \mathrm{RuCO}(\mu-\mathrm{H}) \mathrm{BH}_{2} \mathrm{~L}\right]\left(\mathrm{Cp}^{*}=\eta^{5}-\mathrm{C}_{5} \mathrm{Me}\right.$; $\left.\mathrm{L}=\mathrm{C}_{7} \mathrm{H}_{4} \mathrm{NS}_{2}\right)$ with terminal and internal alkynes: Characterization of vinyl hydroborate and vinyl complexes of ruthenium. Polyhedron 2017, 125, 246-252. (d) Gomosta, S.; Saha, K.; Kaur, U.; Pathak, K.; Roisnel, T.; Phukan, A. K.; Ghosh, S. Hydroboration of Alkynes: $\eta^{4}$-Alkene-Borane versus $\eta^{4}$-E-Boratabutadiene: Inorg. Chem. 2019, 58, 9992-9997.

(12) Anju, R. S.; Saha, K.; Mondal, B.; Dorcet, V.; Roisnel, T.; Halet, J.-F.; Ghosh, S. Chemistry of Diruthenium Analogue of Pentaborane(9) With Hetero-cumulenes: Towards Novel Trimetallic Cubane-type Clusters. Inorg. Chem. 2014, 53, 10527-10535.

(13) (a) Lenczyk, C.; Roy, D. K.; Oberdorf, K.; Nitsch, J.; Dewhurst, R. D.; Radacki, K.; Halet, J.-F.; Marder, T. B.; Bickelhaupt, M.; Braunschweig, H. Toward Transition-Metal-Templated Construction of Arylated $\mathrm{B}_{4}$ Chains by Dihydroborane Dehydrocoupling. Chem. Eur. J. 2019,25, 16544-16549. (b) Yuvaraj, K.; Roy, D. K.; Geetharani, K.; Mondal, B.; Anju, V. P.; Shankhari, P.; Ramkumar, V.; Ghosh, S. Chemistry of Homo and Heterometallic Bridged-Borylene Complexes. Organometallics 2013, 32, 2705-2712. (c) Sharmila, D.; Mondal, B.; Ramalakshmi, R.; Kundu, S.; Varghese, B.; Ghosh, 
S. First-row Transition Metal-Diborane and Borylene Complexes. Chem. Eur. J. 2015,21, 5074-5083. (d) Sharmila, D.; Yuvaraj, K.; Barik, S. K.; Roy, D. K.; Chakrahari, K. K.; Ramalakshmi, R.; Mondal, B.; Varghese, B.; Ghosh, S. Novel Heteronuclear Bridged-Borylene Complexes Derived from $\left[\mathrm{Cp}^{*} \mathrm{CoCl}\right]_{2}$ and Mono-Metal Carbonyl Fragments $\left(\mathrm{Cp}^{*}=\eta^{5}-\right.$ C5Me5). Chem. Eur. J. 2013, 19, 15219-15225.

(14) Anju, R. S.; Roy, D. K.; Geetharani, K.; Mondal, B.; Varghese, B.; Ghosh, S. A fine tuning of metallaborane to bridged-boryl complex, $\left[(\mathrm{Cp} * \mathrm{Ru})_{2}(\mu-\mathrm{H})(\mu-\mathrm{CO})(\mu-\mathrm{Bcat})\right]$ (cat $=1,2-\mathrm{O}_{2} \mathrm{C}_{6} \mathrm{H}_{4}$; $\left.\mathrm{Cp}^{*}=\eta^{5}-\mathrm{C}_{5} \mathrm{Me} 5\right)$. Dalton Trans. 2013, 42, 12828-12831.

(15) Saha, K.; Kaur, U.; Kar, S.; Mondal, B.; Joseph, B.; Sudhadevi, P. K.; Antharjanam; Ghosh, S. Trithia-diborinane and Bis(bridging-boryl) Complexes of Ruthenium Derived from a $\left[\mathrm{BH}_{3}\right.$ (SCHS)]- Ion. Inorg. Chem. 2019, 58, 2346-2353.

(16) Stennett, T. E.; Mattock, J. D.; Vollert, I.; Vargas, A.; Braunschweig, H. Unsymmetrical, Cyclic Diborenes and Thermal Rearrangement to a Borylborylene. Angew. Chem. Int. Ed. 2018, 57, 4098-4102.

(17) Perdew, J. P.; Burke, K.; Ernzerhof, M. Generalized Gradient Approximation Made Simple. Phys. Rev. Lett. 1996, 77, 38653868.

(18) Weigend, F.; Ahlrichs, R. Balanced basis sets of split valence, triple zeta valence and quadruple zeta valence quality for $\mathrm{H}$ to Rn: Design and assessment of accuracy Phys. Chem. Chem. Phys. 2005, 7, 3297-3305.

(19) EMSL Basis Set Exchange Library. https://bse.pnl.gov/bse/portal

(20) Andrae, D.; Häußermann, U.; Dolg, M.; Stoll, H.; Preu $\beta, H$. Energy-adjusted ab initio pseudopotentials for the second and third row transition elements Theor. Chim. Acta. 1990 77, 123-141.

(21) Wiberg, K. Application of the POPLE-SANTRY-SEGAL CNDO method to the cyclopropylcarbinyl and cyclobutyl cation and to bicyclobutane Tetrahedron 1968,24,1083-1096.

(22) Saha, K.; Kaur, U.; Borthakur, R.; Ghosh S. Synthesis of Trithiaborinane Complexes Stabilized in Diruthenium Core: $\left[(\mathrm{Cp} * \mathrm{Ru})_{2}\left\{\left(\eta^{1}-\mathrm{S}\right)\left(\eta^{1}-\mathrm{CS}\right)\left(\mathrm{CH}_{2}\right)_{2} \mathrm{~S}_{3} \mathrm{BR}\right] \quad(\mathrm{R}=\mathrm{H}\right.$ or $\mathrm{SMe})$. Inorganics 2019, 7, 21 .

(23) Saha, K.; Ghorai, S.; Kar, S.; Saha, S.; Halder, R.; Raghavendra, B.; Jemmis, E. D.; Ghosh, S. Stabilization of Classical [B $\left.{ }_{2} \mathrm{H}_{5}\right]-$ Structure and Bonding of $\left[\left(\mathrm{Cp}^{*} \mathrm{Ta}\right)_{2}\left(\mathrm{~B}_{2} \mathrm{H}_{5}\right)(\mu-\mathrm{H}) \mathrm{L} 2\right]\left(\mathrm{Cp}^{*}=\eta^{5}\right.$. $\left.\mathrm{C}_{5} \mathrm{Me}_{5} ; \mathrm{L}=\mathrm{SCH}_{2} \mathrm{~S}\right)$. Angew. Chem. Int. Ed. 2019, 58, 1768417689.

(24) Kaneko, T.; Ninagawa, H.; Matsuoka, M.; Takao T. Synthesis and Properties of a Triruthenium Hydrido Complex Capped by a $\mu_{3}$-Oxoboryl Ligand. Organometallics $\mathbf{2 0 1 9}, 38,2239$ 2249.

(25) Lei, X.; Shang, M.; Fehlner, T. P. Chemistry of Dimetallaboranes Derived from the Reaction of $\left[\mathrm{Cp}^{*} \mathrm{MCl}_{2}\right]_{2}$ with Monoboranes ( $\left.\mathrm{M}=\mathrm{Ru}, \mathrm{Rh} ; \mathrm{Cp}^{*}=\eta^{5}-\mathrm{C}_{5} \mathrm{Me}_{5}\right)$. J. Am. Chem. Soc. 1999, 121, 1275-1287.

(26) Rao, C. E; Yuvaraj K.; Ghosh, S. Diruthenium Analogues of Hexaborane(10) and Pentaborane(9): Synthesis and Structural Characterization of $\left[(1,2-\mathrm{Cp} * \mathrm{Ru})_{2} \mathrm{~B}_{2} \mathrm{H}_{6} \mathrm{~S}_{2}\right]$ and $\left[(2,3-\mathrm{Cp} * \mathrm{Ru})_{2} \mathrm{~B}_{3} \mathrm{H}_{6}\left(\mu-\eta^{1}-\mathrm{EPh}\right)\right], \quad(\mathrm{E}=\mathrm{S}, \mathrm{Se}$ and Te $)\left(\mathrm{Cp}^{*}=\eta^{5-}\right.$ $\left.\mathrm{C}_{5} \mathrm{Me} 5\right)$. J. Organomet. Chem. 2015, 776, 123-128.

(27) (a) Wade, K. The structural significance of the number of skeletal bonding electron-pairs in carboranes, the higher boranes and borane anions, and various transition-metal carbonyl cluster compounds. J. Chem. Soc., Chem. Commun., 1971,792-793. (b) Wade, K. Structural and Bonding Patterns in Cluster Chemistry. Adv. Inorg. Chem. Radiochem. 1976, 18, 1-66.

(28) Rauchfuss, T. B.; Rodgers, D. P. S.; Wilson, S. R. Synthesis of a New Type of Metal Dithiolene Complex via an Induced

New synthetic methods for ruthenium borylene and boryl complexes have been developed. Thermolysis of arachnoruthenaborane, $\left[(\mathrm{Cp} * \mathrm{Ru})_{2} \mathrm{~B}_{3} \mathrm{H}_{8}\left(\mathrm{CS}_{2} \mathrm{H}\right)\right]$ with phenyl acetylene led to the formation of ruthenium bridging boryl borylene complex, $\left[\left(\mathrm{Cp}^{*} \mathrm{Ru}\right)_{2}\left(\mu-\mathrm{HBS}_{2} \mathrm{CH}_{2}-\kappa^{2} B: \kappa^{2} S\right)\left\{\mu-\mathrm{B}\left(\mathrm{C}_{6} \mathrm{H}_{4}\right) \mathrm{C}(\mathrm{Me})-\kappa^{2} B: \kappa^{2} C\right\}\right]$ via the hydroboration of alkyne (see picture).
Reaction of Acetylenes with a Ruthenium Sulfide. J. Am. Chem. Soc. 1986, 108, 3114-3115.

(29) (a) Koren-Selfridge, L.; Query, I. P.; Hanson, J. A.; Isley, N. A.; Guzei, I. A.; Clark, T. B. Synthesis of Ruthenium Boryl Analogues of the Shvo Metal-Ligand Bifunctional Catalyst. Organometallics 2010,29, 3896-3900. (b) Braunschweig, H.; Kollann, C.; Klinkhammer, K. W. Boryl and Bridged Borylene Complexes of Iron and Ruthenium. Eur. J. Inorg. Chem. 1999, 1523-1529. (c) Yasue, T.; Kawano, Y.; Shimoi, M. Syntheses and Structures of Trimethylphosphine-complexed Primary Boryl Complexes of Group 8 Metals, $\mathrm{Cp}^{*} \mathrm{M}(\mathrm{CO})_{2}\left(\mathrm{BH}_{2} \cdot \mathrm{PMe}_{3}\right)$ $(\mathrm{M}=\mathrm{Fe}, \mathrm{Ru})$. Chem. Lett. 2000, 29, 58-59. (d) Braunschweig, H.; Koster, M.; Wang, R. Diborane(4)yl Complexes of Molybdenum and Ruthenium. Inorg. Chem. 1999, 38, 415416. (e) McQueen, C. M. A.; Hill, A. F.; Sharma, M.; Singh, S. K.; Ward, J. S.; Willis, A. C.; Young, R. D. Synthesis and reactivity of osmium and ruthenium PBP-LXL boryl pincer complexes. Polyhedron 2016, 120, 185-195. (f) Miyada, T.; Kwan, E. H.; Yamashita, M. Synthesis, Structure, and Bonding Properties of Ruthenium Complexes Possessing a Boron-Based PBP Pincer Ligand and Their Application for Catalytic Hydrogenation. Organometallics 2014, 33, 6760-6770. (g) Murphy, J. M.; Lawrence, J. D.; Kawamura, K.; Incarvito, C.; Hartwig, J. F. Ruthenium-Catalyzed Regiospecific Borylation of Methyl C-H Bonds. J. Am. Chem. Soc. 2006, 128, 13684 13685. (h) Braunschweig, H.; Damme, A.; Dewhurst, R. D.; Radacki, K.; F. Weißenberger, Wennemann, B.; Ye, Q. Fundamental Differences between Group 8 Metals: Unexpected Oxidation State Preferences and Mechanisms in Ruthenium Borylene Complex Formation. Chem. Eur. J. 2016 22, 8471-8474. (i) Yamamoto, K.; Mohara, Y.; Mutoh, Y.; Saito; S. Ruthenium-Catalyzed (Z)-Selective Hydroboration of Terminal Alkynes with Naphthalene-1,8-diaminatoborane. J. Am. Chem. Soc. 2019, 141, 17042-17047.

(30) Hermanek, S. ${ }^{11}$ B NMR Spectra of Boranes, Main-Group Heteroboranes, and Substituted Derivatives. Factors Influencing Chemical Shifts of Skeletal Atoms. Chem. Rev. 1992, 92, 325-362.

(31) Koelle, U.; Kossakowski, J.; Grumbine, D.; Tilley, T. D. Di- $\mu$ Chloro-Bis [( $\eta^{5}$-Pentamethylcyclopentadienyl)-

Chlororuthenium (III)], $\left\{\mathrm{Cp}^{*} \mathrm{RuCl}_{2}\right]_{2}$ and Di- $\mu$-methoxoBis( $\eta^{5}$-Pentamethylcyclopentadienyl)-dirutheniu m(II), [Cp*RuOMe]2. Inorg. Synth. 1992,29, 225-228.

(32) Lalancette, J. M.; Frêche. A.; Monteux. R. Reductions with sulfurated borohydrides. I. Preparation of sulfurated borohydrides. Can.J. Chem. 1968, 46, 2754-2757.

(33) Altomare, A.; Cascarano, G.; Giacovazzo, C.; Guagliardi, A.; Burla, M. C.; Polidori, G.; Camalli, M. SIR92 - a program for automatic solution of crystal structures by direct methods, $J$. Appl. Crystallogr. 1994, 27, 435-436.

(34) Sheldrick, G. M. Crystal structure with SHELXL, Acta Crystallogr. Sect. C 2015, 71, 3-8.

(35) Dolomanov, O. V.; Bourhis, L. J.; Gildea, R. J.; Howard, J. A. K.; Puschmann, H. OLEX': a complete structure solution, refinement and analysis program, J. Appl. Cryst. 2009, 42, 339-341. 


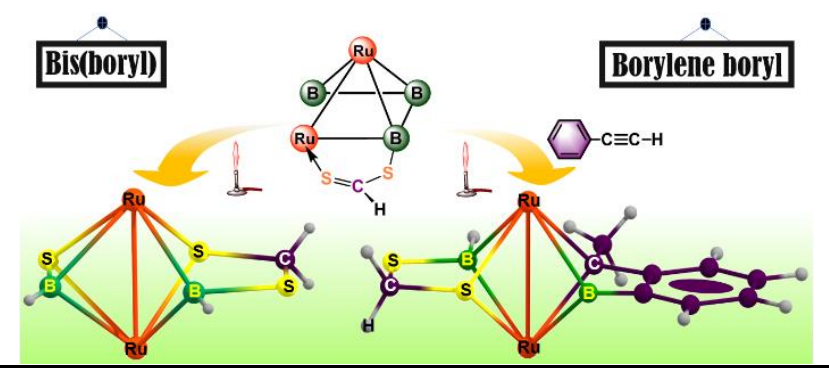

